Review

\title{
Review of Micro-Nanoscale Surface Coatings Application for Sustaining Dropwise Condensation
}

\author{
Shoukat Alim Khan ${ }^{1,2, *}$, Furqan Tahir ${ }^{1}$, Ahmer Ali Bozdar Baloch ${ }^{1}(\mathbb{C})$ and Muammer Koc ${ }^{1}$ (i) \\ 1 Division of Sustainable Development (DSD), College of Science and Engineering (CSE), Hamad Bin Khalifa \\ University (HBKU), Education City, Doha P.O. Box 5825, Qatar; ftahir@mail.hbku.edu.qa (F.T.); \\ ahmbaloch@mail.hbku.edu.qa (A.A.B.B.); mkoc@hbku.edu.qa (M.K.) \\ 2 Faculty of Mechanical Engineering, The Ghulam Ishaq Khan Institute of Engineering Sciences and \\ Technology, Topi, Swabi, Khyber Pakhtunkhwa 23640, Pakistan \\ * Correspondence: shokhan@hbku.edu.qa or Shoukat.alimkhan@gmail.com
}

Received: 12 January 2019; Accepted: 6 February 2019; Published: 13 February 2019

\begin{abstract}
Condensation occurs in most of the heat transfer processes, ranging from cooling of electronics to heat rejection in power plants. Therefore, any improvement in condensation processes will be reflected in the minimization of global energy consumption, reduction in environmental burdens, and development of sustainable systems. The overall heat transfer coefficient of dropwise condensation (DWC) is higher by several times compared to filmwise condensation (FWC), which is the normal mode in industrial condensers. Thus, it is of utmost importance to obtain sustained DWC for better performance. Stability of DWC depends on surface hydrophobicity, surface free energy, condensate liquid surface tension, contact angle hysteresis, and droplet removal. The required properties for DWC may be achieved by micro-nanoscale surface modification. In this survey, micro-nanoscale coatings such as noble metals, ion implantation, rare earth oxides, lubricant-infused surfaces, polymers, nanostructured surfaces, carbon nanotubes, graphene, and porous coatings have been reviewed and discussed. The surface coating methods, applications, and enhancement potential have been compared with respect to the heat transfer ability, durability, and efficiency. Furthermore, limitations and prevailing challenges for condensation enhancement applications have been consolidated to provide future research guidelines.
\end{abstract}

Keywords: filmwise condensation; micro-nano; surface coatings; heat transfer; phase change

\section{Introduction}

The phase change heat transfer (PCHT) participates in almost every energy conversion application, from small-scale processor cooling to large-scale power plants [1]. The main advantage with PCHT is that large amounts of heat can be transferred with a small temperature difference [2-5]. It is estimated that $50 \%$ of desalination plants and $85 \%$ of power generation plants worldwide are steam condenser-based [6,7]. However, due to poor thermal efficiency of PCHT processes, related losses and required footprints are high. Therefore, any improvement in heat transfer will lead to an overall efficiency improvement, resulting in lower capital/operating expenditures (CAPEX/OPEX) and environmental burdens. Heat transfer enhancement requires physical improvements in the system, and with a wide range of PCHT applications, slight improvements may outcome in significant energy, economic, and environmental impacts [8-11]. In PCHT applications, boiling/evaporation and condensation phenomena dominate; these processes are similar to each other in terms of variable dependency [1]. Both are surface phenomena and depend upon variables such as the nature of the working fluid, solid surface, and the interaction surface between them. However, the conditions of the interaction surface affecting boiling and condensation are dissimilar. For example, hydrophilic surface 
increases the maximum ability of heat transfer in boiling by delaying the vapors' film formation, while in condensation, they result in the formation of liquid film and hence decrease the performance of the surface. Similarly, hydrophobic coating provides improved performance in condensation, but results in reduced performance in boiling. In addition, the topographic nature of coatings has different effects for boiling and condensation. For example, porous coatings have advantages for boiling in terms of critical heat flux (CHF) and heat transfer coefficient (htc), while for condensation, these coatings are not efficient. Therefore, for better understanding, boiling and condensation should be studied distinctly.

Condensation is a process in which the gaseous phase changes into the liquid phase by releasing energy, which is usually involved in heat rejection systems/condensers $[12,13]$. Water vapors or refrigerant vapors condense in condensers of power plant, desalination, or air conditioning systems by rejecting heat to cooling water, which is usually from the sea, canals, or rivers. Following are some examples of room for improvements/disadvantages associated with industrial-based condensers:

- Industrial-based condenser is mostly shell and tube exchangers and requires a high heat transfer area, which indicates higher footprints [14].

- In addition, a huge amount of cooling water is required, which reflects in more pumping power and intake/outfall footprints.

- The heat absorbed by cooling water from the condenser is dumped back into the water source. In some plants, such as desalination, the condenser is used as a preheater, but approximately one part out of ten is used as feed and the remaining nine parts are pumped back to the sea [15].

- Rejected cooling water has higher temperature and may affect the environment and marine life [16].

Therefore, condenser load should be minimized by process optimization, and condensation process enhancement is needed for an efficient and sustainable system. Figure 1 shows the condensation process outside the tube surface, where condensation heat transfer by the vapor phase is taken away by the cooling medium flowing inside the tube. The heat transfer is governed by an overall heat transfer coefficient, which is the reciprocal of total thermal resistance.

$$
q=U \Delta T=\frac{1}{R_{t o t}} \Delta T
$$

and from the thermal resistance network:

$$
R_{\text {tot }}=R_{\text {cool }}+R_{w}+R_{\text {cond }}
$$

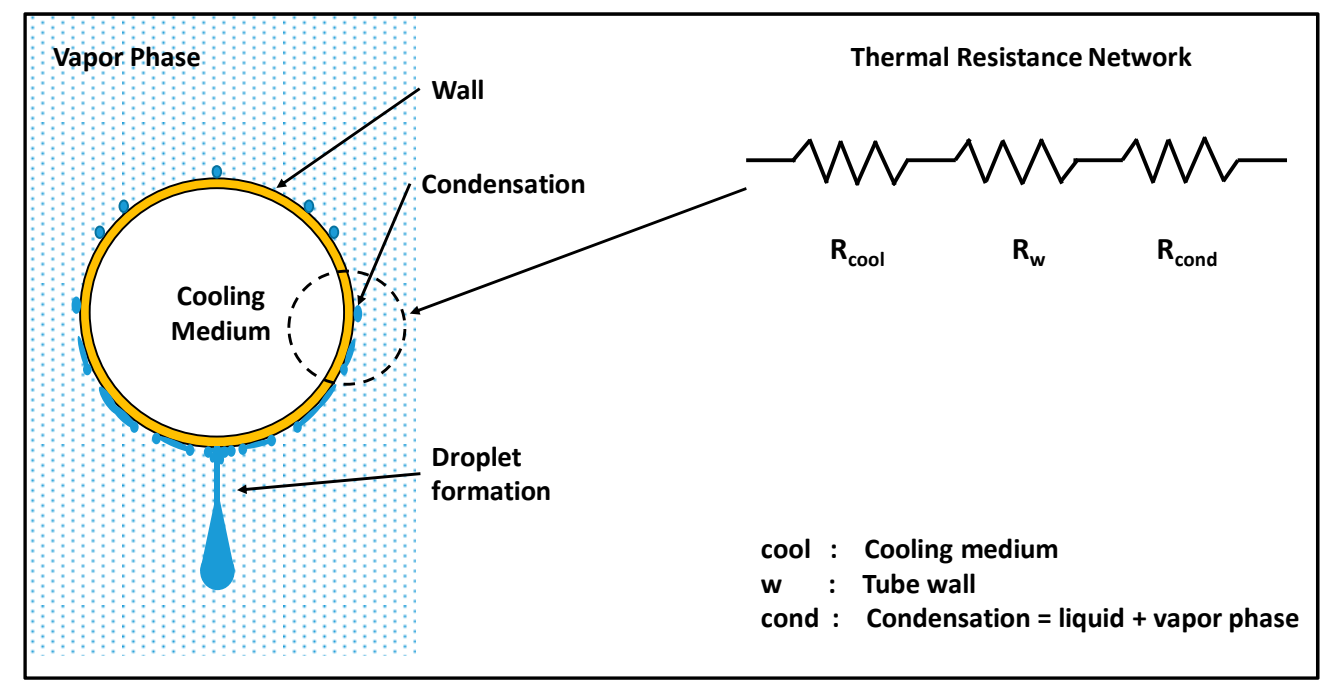

Figure 1. Condensation outside the tube surface and thermal resistance $(R)$ network. 
Any decrement in thermal resistance will affect the efficiency of the heat transfer process. For cooling medium, nanoparticles can be used to decrease thermal resistance, but this has complications of added operating cost and environmental effects. Condensation thermal resistance can be reduced by surface modifications and one way is to promote dropwise condensation $[17,18]$. Tube surface modification offers numerous ways to minimize thermal resistance. Figure 2 shows PCHT enhancement techniques, which are classified into active and passive methods [19]. Active methods involve external power while in passive methods; no external power is required. Compound methods are combinations of two or more passive and/or active techniques that are employed together.

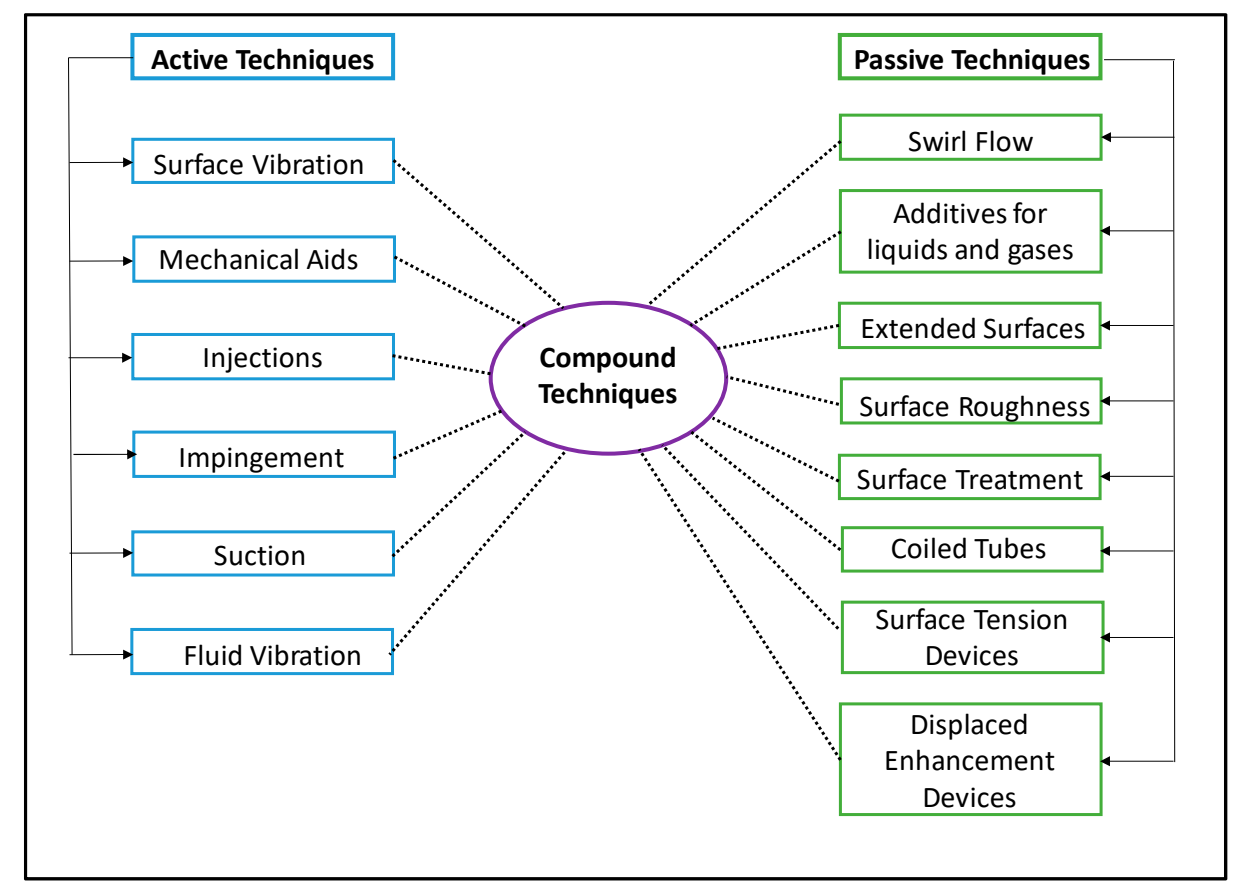

Figure 2. Phase change heat transfer (PCHT) enhancement methods with active and passive techniques.

Surface treatment deals with the coating or alteration of surface structure at fine scale from the micro- to nanoscale. Recent developments in the field of micro-nano manufacturing and surface functionalization have expanded the boundaries for heat transfer enhancement through surface treatment and modification [20-22]. Surface coating provides room for modification as per the application. Surface coating application is more versatile in material selection and quite practical to implement in already-installed surface systems. Specific textures to complex geometries can be added to a surface by various coating techniques such as sintering, spraying and plasma coating, gluing, electroplating, and 3D printing. Materials such as metals, polymers, ceramics, and composites in complex geometries and shapes such as 3D porous structures, pyramid, bumps, and pillars in micro-nanoscales can be developed through surface coating. Topology is a surface geometric property that varies with pitch, shape, height, and depth. Each significantly affects surface characteristics, which in turn changes the overall heat transfer coefficient in both condensation and boiling/evaporation. This indicates countless possibilities for surface modification and provides ample room for improvement of heat transfer for various applications' needs and constraints [23]. Survey studies are available in the literature focusing on boiling enhancement by micro-nano surface coatings [1,24], nanofluids [25-27], and dropwise condensation [28-30]. Furthermore, numerical studies have been carried out to understand PCHT at the micro/nano level. Some of the examples are as follows: Gusarov and Smurov [31] analyzed the Knudsen layer for phase change heat transfer. Zhu and Ye [32] performed Monte Carlo simulations to evaluate heat transfer for micro/nano devices. Liu et al. [33] used a kinetic model based on multiple temperatures for gas flows at the micro level. Zheng et al. [34] implemented a hybrid thermal lattice Boltzmann method to investigate dropwise condensation (DWC). Although 
experimental and theoretical work is of equal importance, the focus of this paper is oriented towards experiments involving DWC enhancements.

The aim of this study is to consolidate surface coating methods applied for external condensation process augmentation; specifically, with recently developed micro-nanoscale coating techniques for modification of surface geometry and chemistry. Available coatings include ion implantation, noble metals (gold, silver, platinum, palladium, and rhodium), rare earth oxides (lanthanide series), polymers (fluoropolymers), self-assembled monolayers (thiol and saline), lubricant-infused surfaces, porous coatings, and emerging materials (carbon nanotubes, graphene, diamond-like carbon, carbon fiber, and nanostructured surfaces). The surface coating methods, applications, and enhancement potentials have been compared with respect to cost, robustness, durability, and efficiency. Moreover, limitations and existing challenges for condensation enhancement applications have been presented.

\section{Condensation: Phase Change Heat Transfer Process}

The phenomenon of condensation occurs when vapor, in a saturated or supersaturated phase, makes contact with a surface/wall or fluid at a lower saturation temperature [35]. Due to lower energy barrier in almost all industrial applications, vapors are condensed on the surface instead of its direct condensation [36]. Convection mode dominates in the condensation process, in which surface tension and density difference are key factors that make the flow buoyancy-driven. Natural convection and latent heat enable higher heat transfer rate as compared to single-phase convection [37]. There are two main types of condensation: namely, dropwise (DWC) and filmwise (FWC) condensation, as shown in Figure 3. In DWC, droplets form as condensation occurs and move in a discontinuous fashion, while in FWC, a continuous thin liquid film is formed and the cold surface is completely covered, due to which thermal resistance increases, resulting in lower heat transfer coefficient.
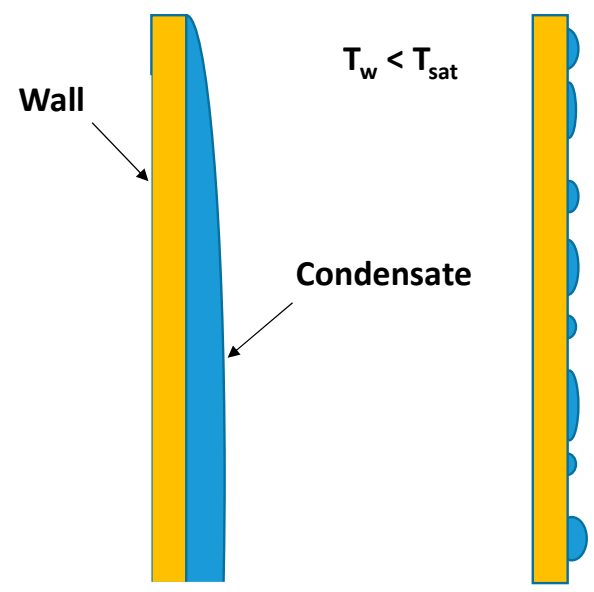

(a)

(b)

Figure 3. Schematic of (a) filmwise condensation and (b) dropwise condensation, where $T_{\mathrm{w}}$ is the wall temperature and $T_{\text {sat }}$ is the saturation temperature of the fluid.

\subsection{Dropwise Condensation (DWC)}

At the start of condensation phenomenon, liquid droplets appear on the cold surface due to heat flow from vapors to cold substrate [38]. However, the mechanism of drop formation is still not clear regarding whether they are the result of a very thin liquid film on the surface [39] or direct nucleation of drops which then grow further [40]. Rykaczewski et al. [5] reported formation of small micro-nanoscale satellite drops and comparatively big primary drops on a superhydrophobic condenser surface. It was noted that the primary drops sweep up these small satellite drops without covering their area of nucleation. Primary drops assist in transferring heat while satellite drops renucleate, as shown in Figure 4 . The number of coalescence drops can reach up to 400,000 , depending on surface quality, before sliding off from the surface [41]. This removal of condensate in drops formed in its initial stage 
of condensate nucleation on substrate surface is known as dropwise condensation. As the size of the droplet grows, its capacity for thermal resistance increases and the phenomenon shifts towards FWC. For these reasons, a certain size of drops is more favorable in condensation to provide new nucleation points and area for direct contact of vapor with cold substrate. For efficient removal, droplet size should be less than the liquid capillary length [42]. Condensation phenomena with the departure size of condensate lower than its capillary length ( $\sim 3 \mathrm{~mm}$ for water) have better heat transfer (HT) performance as faster renucleation is possible [43]. Droplet detachment size increases with an increase of surface tension and decreases with surface tilt angle and liquid contact angle [44]. Overall condensation resistance $\left(R_{\text {cond }}\right)$ in DWC is a function of the substrate resistance $\left(R_{\text {sub }}\right)$, liquid droplet resistance $\left(R_{1}\right)$, and mass transfer at the liquid-vapor interface resistance $\left(R_{\text {int }}\right)[45,46]$. At the start of condensation, for small droplet size, $R_{\text {int }}$ dominates over $R_{1}$, but with the increase of droplet size, $R_{1}$ may dominate over $R_{\text {int }}$ [42]. The heat transfer coefficient for DWC is reduced for lower pressures. There are lengthy expressions for calculating heat transfer coefficient (htc) in the literature. However, a simple correlation was proposed for heat flux as a function of temperature difference between vapor and surface and absolute temperature only [47].

$$
\frac{q}{1000}=(T-273.15)^{0.8}\left[5 \Delta T+0.3 \Delta T^{2}\right]
$$

Equation (3) was developed using experimental data for vertical plates, but the correlation can also be used for DWC on horizontal tubes with maximum underestimation of $20 \%$. The achievement of DWC for any condenser represents higher performance or efficiency improvement.

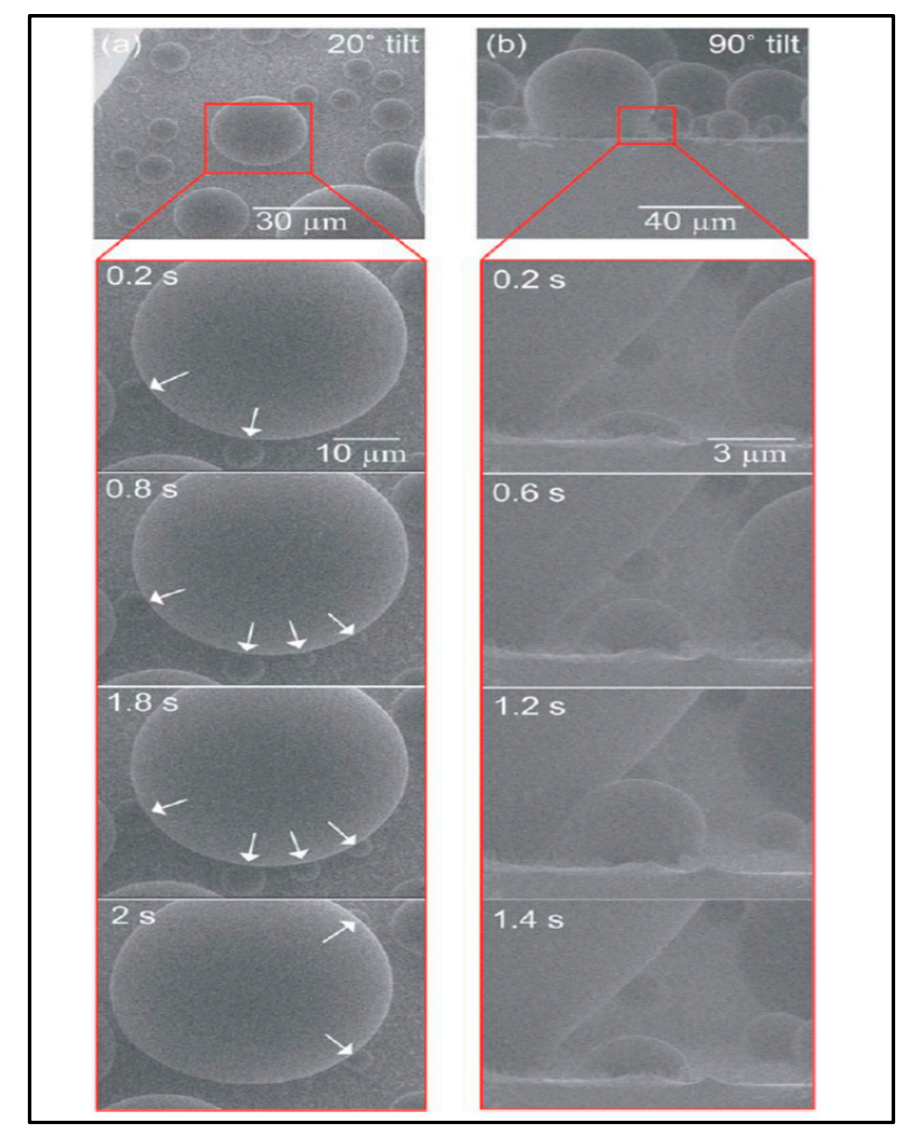

Figure 4. Location of small micro-nanoscale satellite drops adjacent to primary drops as shown by white arrows. Images taken by Environmental Scanning Electron Microscopy (ESEM) at (a) $20^{\circ}$ and (b) $90^{\circ}$ tilt on a super hydrophobic condenser surface [5]. Reprinted with permission from Ref. [5]. Copyright 2011 Royal Society of Chemistry. 


\subsection{Filmwise Condensation (FWC)}

FWC is the most common situation occurring in real-life industrial applications. If the rate of condensate drops' formation is more than its removal, then these drops merge and form a liquid film. Formation of liquid film blocks direct contact of vapor and substrate surface and hence establishes an extra resistance to the condensation process. Due to this reason, FWC is a relatively poor form of condensation when compared to DWC in terms of its efficiency and performance. Transformation to FWC from DWC is undesirable for every condensation process after certain limits of time, surface quality declination, or temperature. The causes of DWC transition to FWC are:

- The density of nucleation sites increases with a rise in temperature difference between the vapor and cool substrate. These drops merge with neighboring drops and after a certain limit, form a liquid film on the surface.

- Higher heat flux results in increased droplet size, which leads toward film condensation [47].

Nusselt [48] evaluated the heat transfer coefficient for a vertical plate and horizontal tube for FWC. It was assumed that the gaseous phase is pure vapor, flow is in laminar regime, and convection effects are negligible.

For vertical plate:

$$
\text { htc }=0.943\left[\frac{\rho_{1}\left(\rho_{1}-\rho_{\mathrm{v}}\right) g h_{l g} k_{l}^{3}}{\mu_{\mathrm{L}} L(\Delta T)}\right]^{\frac{1}{4}}
$$

For horizontal tube:

$$
\text { htc }=0.728\left[\frac{\rho_{\mathrm{l}}\left(\rho_{1}-\rho_{\mathrm{v}}\right) g h_{l g} k_{l}^{3}}{\mu_{\mathrm{L}} L(\Delta T)}\right]^{\frac{1}{4}}
$$

For different modification parameters, DWC is at least one order of magnitude higher in its heat transfer performance than FWC $[47,49,50]$. For industrial applications of DWC, durability of modified surface is still a challenge [44,51].

\subsection{Noncondensable Gases}

Noncondensable gases act as a source of high thermal resistance [52]. The effect of noncondensable gases on the condensation process is substantial and a point of interest for many studies [53-55]. Due to high thermal resistance, even a small amount of noncondensable gases plays a major role in slowing down the overall condensation process. For accurate measurements of the condensation process, it is required to minimize their quantity to prevent a diffusion boundary layer, as noteworthy error can result even from the tiny quantity of $3 \mathrm{ppm}(\mu \mathrm{mol} / \mathrm{mol})[47,56,57]$.

\subsection{Optimal Surface Conditioning}

DWC, FWC, or a combination of both can be observed on the heat transfer surface as per operating conditions. Resultant form of condensate depends mainly on the roughness [58], surface orientation [59], and surface tension of condensing fluid [60,61]. Extensive efforts have been made to lower surface energy in order to achieve stable DWC mode for longer periods for real-life applications [62]. Surfaces can be modified for condensation enhancement by increasing their ability to produce and sustain DWC and achieve proper drainage of liquid film in FWC [23]. Three main methods for enhancing condensation are:

- Changing surface chemistry and energy [63-65];

- Changing surface geometry, i.e., via roughening, fins, and external modifications on condenser tubes [66];

- Use of external forces to enhance condensing phenomena (active method). 
The first two techniques can be applied by surface modification, while the third method involves gravitational force, surface tension, and shear forces in the droplet detachment from the surface and affects the condensation process [23]. Modifying these forces by application of an external source can affect the overall condensation process. However, the application of such techniques for condensation enhancement is out of the scope of this paper.

\subsection{Surface Roughness: from Young's to Wenzel and Cassie States}

When the liquid droplet touches a flat surface, it makes a certain contact angle with the surface depending upon the surface's free energy. The contact angle is determined by the hydrophilicity or hydrophobicity of the surface. Young [67] proposed the following relationship to evaluate contact angle:

$$
\cos \theta=\frac{\gamma_{\mathrm{sv}}-\gamma_{\mathrm{sl}}}{\gamma_{\mathrm{lv}}}
$$

where $\gamma_{\mathrm{sv}}, \gamma_{\mathrm{sl}}$, and $\gamma_{\mathrm{lv}}$ represents interfacial energies between the surface (substrate) and vapor, surface and liquid, and liquid and vapor, respectively, as shown in Figure 5. For rough surfaces, this equation is modified, as described by Wenzel [68]. When liquid fully covers a rough surface, the apparent contact angle is defined as:

$$
\cos \theta_{\mathrm{wz}}=r \cos \theta
$$

where $r$ is the roughness ratio, which is the total surface area divided by projected area. Cassie and Baxter [69] found that at some conditions, liquid droplet rests on the tips of a roughened surface and the apparent contact angle can be evaluated as:

$$
\cos \theta_{\mathrm{c}}=\varphi(\cos \theta+1)-1
$$

where $\varphi$ is the ratio of the contacting solid area to the projected area of the droplet. The three states of drops that exist in condensation are suspended (S) /Cassie (C), Wenzel (W), and partially wetted (PW), as shown in Figure 6. Morphology of droplet, i.e., W, PW, or S, is strongly dependent on surface geometry and nucleation density. Wenzel-state droplets have high wettability due to more adhesion to the surface as compared to the Cassie state, and hence are less desired. Many studies were conducted on creating hydrophobic surfaces to limit droplet adhesion [70].

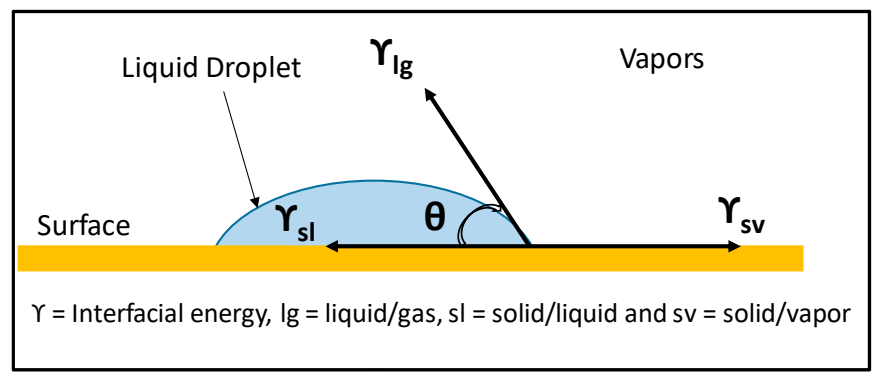

Figure 5. Young's contact angle measurement.

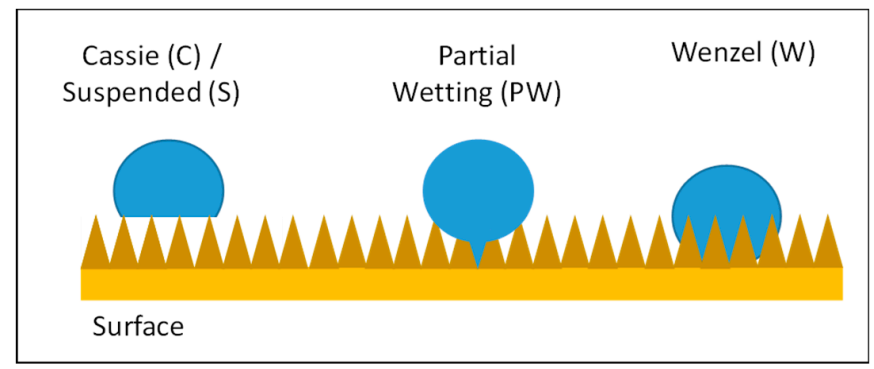

Figure 6. Different states of liquid droplets under different circumstances. 


\subsection{Wettability}

Wettability strongly influences the development and sustaining of DWC and it can be directly measured from the contact angle formed by the resulting liquid drop. Incomplete wettability ensures the enhancement of condensation. High-wettability surfaces are the surfaces with high surface energy and low contact angle. They do not quickly remove the resultant droplets of condensate, and hence these drops grow and join, resulting in FWC [71]. In contrast, surfaces with low wettability have low surface energy, so they assist in the release of drops soon after their formation, which results in DWC. Wettability helps in the enhancement of condensation heat transfer by [23]:

- Encouraging droplet nucleation and early removal, and hence maximizing htc;

- Ensuring drainage of condensate before film formation;

- Sustaining surface quality to maintain its performance for long time.

Changing wettability with a hydrophobic coating ensures removal of the liquid drops, which sustains DWC. Almost all condensation enhancement techniques at the micro-nanoscale, whether involving surface energy modification or morphology modification, are wettability-oriented. Wettability directly affects departure diameter, contact angle, and nucleation density and hence heat transfer performance [72].

\section{Condensation Enhancement by Surface Coatings}

The surface energies of commonly used metals for condenser application, such as copper $(\mathrm{Cu})$, aluminum (Al), stainless steel (SS), and titanium (Ti), are high, which results in high wettability and hence formation of FWC [49]. Surface coatings have been applied in many studies to reduce surface energy and to achieve DWC [73-75]. Figure 7 shows a copper surface with some part of it coated with a film and the rest untreated. Coated locations demonstrate DWC, while bare parts of the surface are covered with a liquid layer, which indicates FWC [76]. Different types of surface coatings have been tested for condensation enhancement, such as inorganic compounds, noble metals, polymers, surface alloys, and organic compounds (for steam/high-surface-tension fluid systems) [77-80]. For each surface modification type and technique, there are advantages and disadvantages associated with them. The main parameters to evaluate different coatings are hydrophobicity, thermal resistance/conductivity, durability/stability, and cost.

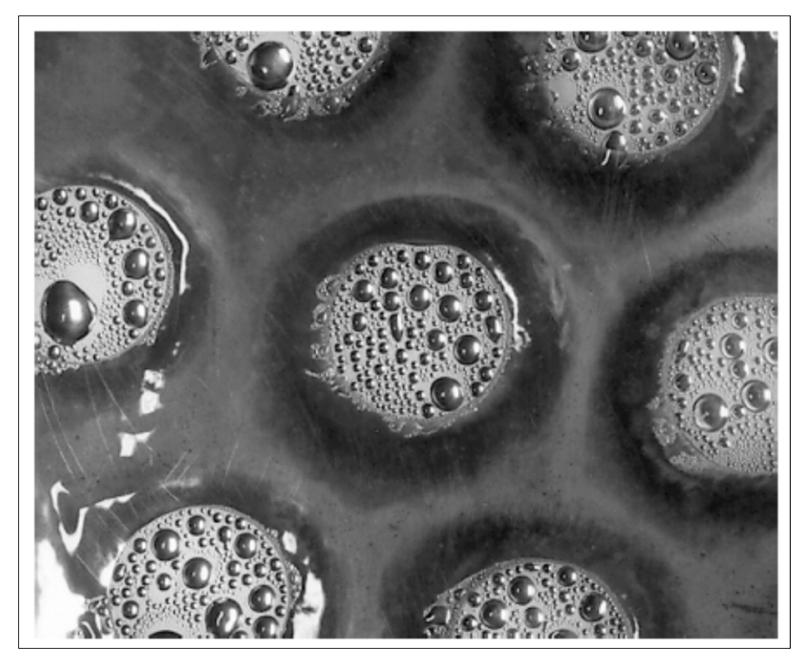

Figure 7. Dropwise condensation on coated and filmwise condensation on uncoated portions of the same substrate [76]. Reprinted with permission from Ref. [76]. Copyright 1997 Springer. 


\subsection{Noble Metals}

Noble metals have the ability to resist corrosion and oxidation. They have higher contact angles with water; for example, silver $(\mathrm{Ag})=68^{\circ}-89^{\circ}$, gold $(\mathrm{Au})=55^{\circ}-85^{\circ}$, rhodium $(\mathrm{Rh})=65^{\circ}-82^{\circ}$, platinum $(\mathrm{Pt})=50^{\circ}$, and palladium $(\mathrm{Pd})=74^{\circ}$, due to lower surface energy [81]. Erb [82] reported that DWC arises naturally on noble metals such as silver, gold, rhodium, chromium, and palladium. Noble metals were formerly considered as the only source for natural DWC [62]. However, later on, the formation of FWC of steam was discovered for pure, clean noble metals [83] before the observation of FWC of steam on noble metals. Noble metals have the innate ability to absorb impurities and hydrocarbons, which helps in the formation of liquid droplets of micron to millimeter size on their surface [83-85]. High price of the material limits their practical application, but the problem can be solved to an extent by using thin coatings. Condensation enhancements by noble metal coatings are summarized in Table 1 .

Woodruff and Westwater [86] studied different thicknesses of gold coatings through electrodeposition on copper substrate for steam. The results showed that thicknesses up to $20 \mathrm{~nm}$ have no clear achievement in enhancement of DWC, while a minimum thickness of $200 \mathrm{~nm}$ was recorded as being required for DWC. Transition region was observed from FWC to DWC as the coating thickness was increased from 20 to $100 \mathrm{~nm}$. However, it is worth noting that the thickness distribution by electrodeposition was not uniform. Smith [87] reported a minimum gold thickness of $100 \mathrm{~nm}$ as a lower limit to obtain DWC on Cu substrate. In addition, Westwater [41] briefly reviewed thin gold coatings' applications for condensation enhancement by achieving DWC and also the direct application of gold surfaces for DWC. He concluded that the brighter and purer the gold coating on a substrate, the higher the DWC that can be achieved. Characterization of silver coatings for DWC of steam has been performed by O'Neill and Westwater [88]. Although the effectiveness of silver and other noble metals in DWC was already known, the effectiveness of minimum thickness and lifetime of these Ag coatings was unknown before this study. The thickness of Ag coating was varied between 0 and $3000 \mathrm{~nm}$ by using an electroplating technique. Temperature difference between the silver plating and steam was varied from 1 to $58 \mathrm{~K}$. They observed heat flux up to $1.5 \mathrm{MW} / \mathrm{m}^{2}$, which was far greater than that of FWC for the same temperature difference. Plates with coatings thicker than $150 \mathrm{~nm}$ were reported to produce DWC, while those thinner than $30 \mathrm{~nm}$ resulted in FWC. Between the different coating thicknesses, a maximum DWC sustaining time of $2400 \mathrm{~h}$ was documented for $300 \mathrm{~nm}$. The effectiveness was decreased due to increasing resistance with their thickness. Instead of only surface modification by silver coating, Gore et al. [35] studied the combined enhancement condensation effect of surface modification by Ag coating and n-heptane surfactant. Surfactant's quantity was varied between 0 and $2 \%$ in a silver-coated condenser. It was concluded that silver coating resulted in increased htc as compared to bare $\mathrm{Cu}$ surface and the addition of surfactants further helped in increasing its condensation htc. In their study, overall enhancement of $57.72 \%$ with $2 \%$ of $\mathrm{n}$-heptane has been reported. It was mentioned that such a coating can be sustained for a long time, but duration was not reported.

Ge et al. [89] studied the effect of noncondensable gas $\left(\mathrm{CO}_{2}\right)$ on steam condensation. Higher $\mathrm{CO}_{2}$ concentrations exist in $\mathrm{CO}_{2}$ capture processes [90] and seawater desalination [91], which affect the condensation process. They performed experiments for a vapor mixture with $45-95 \%$ of $\mathrm{CO}_{2}$ on bare stainless steel (SS) and gold-plated vertical plates. It was found that with rich $\mathrm{CO}_{2}$ concentration, the condensation enhancement was negligible due to increased thermal resistance. However, condensation can be enhanced by adopting finned surface. Erb and Thelen at the Franklin Institute [92,93] evaluated the cost of electrodeposited noble metals for DWC and came up with total cost of around $0.07-0.20 \$ / \mathrm{m}^{2}$. The noble metal coatings enhance the condensation process, but durability is still a challenge and surfactants are required to maintain DWC mode. 
Table 1. Condensation enhancements by noble metal coatings.

\begin{tabular}{cccccccc}
\hline Substrate & $\begin{array}{c}\text { Coated } \\
\text { Metal }\end{array}$ & $\begin{array}{c}\text { Coating } \\
\text { Method }\end{array}$ & $\begin{array}{c}\text { Condensate/ } \\
\text { Environment }\end{array}$ & $\begin{array}{c}\text { Effective } \\
\text { Life of } \\
\text { Coating (h) }\end{array}$ & $\begin{array}{c}\text { Effective Coating } \\
\text { Thickness (nm) }\end{array}$ & $\begin{array}{c}\text { Enhancement } \\
\text { in htc (\%) }\end{array}$ & Ref. \\
\hline $\mathrm{Cu}$ & $\mathrm{Ag}$ & Electroplating & Steam & 2,400 & $300 \mathrm{~nm}$ & $550 \% \max$ & {$[88]$} \\
\hline $\mathrm{Cu}$ & $\begin{array}{c}\mathrm{Ag}(\mathrm{with} \\
\text { n-heptane as } \\
\text { surfactant) }\end{array}$ & - & Steam & - & - & $57 \%$ & {$[35]$} \\
\hline $\mathrm{SS}$ & $\mathrm{Au}$ & Electroplating & Steam/CO & - & $15,000-50,000 \mathrm{~nm}$ & $\begin{array}{c}\text { Negligible (with } \\
\text { rich CO } \mathrm{CO}_{2} \\
\text { environment) }\end{array}$ & {$[89]$} \\
\hline $\mathrm{Cu}$ & $\mathrm{Au}$ & Electroplating & Steam & - & $100 \mathrm{~nm}$ & $\begin{array}{c}\sim 1000 \% \text { max as } \\
\text { compared to } \\
\text { FWC }\end{array}$ & {$[86]$} \\
\hline
\end{tabular}

\subsection{Rare Earth Oxides (REOs)}

Different studies have proved the hydrophobic nature of lanthanide series rare earth oxides and their promotion of DWC [94-96]. The hydrophobic nature of REOs makes them different from other metal oxides. Their unique outer shell electronic configuration of $5 \mathrm{~s}^{2} \mathrm{p}^{6}$ minimizes their interaction with water molecules [96]. Comparison between the water molecule orientation on aluminum oxide (alumina), as a representative metal oxide, and a REO is shown in Figure 8. The ability of an alumina surface to maintain hydrogen bonding means it is hydrophilic. Cost of REOs is less than $1 \%$ of that of noble metal coatings [97], and their thermal conductivity is approximately 50 times higher than fluoropolymers [98]. These properties make REOs favorable for condensation enhancement, but there are still hurdles that need to be overcome for industrial applications [99]. Researchers have developed methods to form coatings at the micro/nanoscale for praseodymium oxide, cerium oxide, gadolinium oxide, holmium oxide, lanthanum oxide, and terbium oxide. Superhydrophobic surfaces can be manufactured from REOs either by laser ablation, textured coating by spray or colloidal process, or by thin film or layer-by-layer deposition on a substrate [96]. Azimi et al. [94] used laser ablation of rare earth oxides for the production of robust superhydrophobic surfaces to investigate their potential for industrial application.

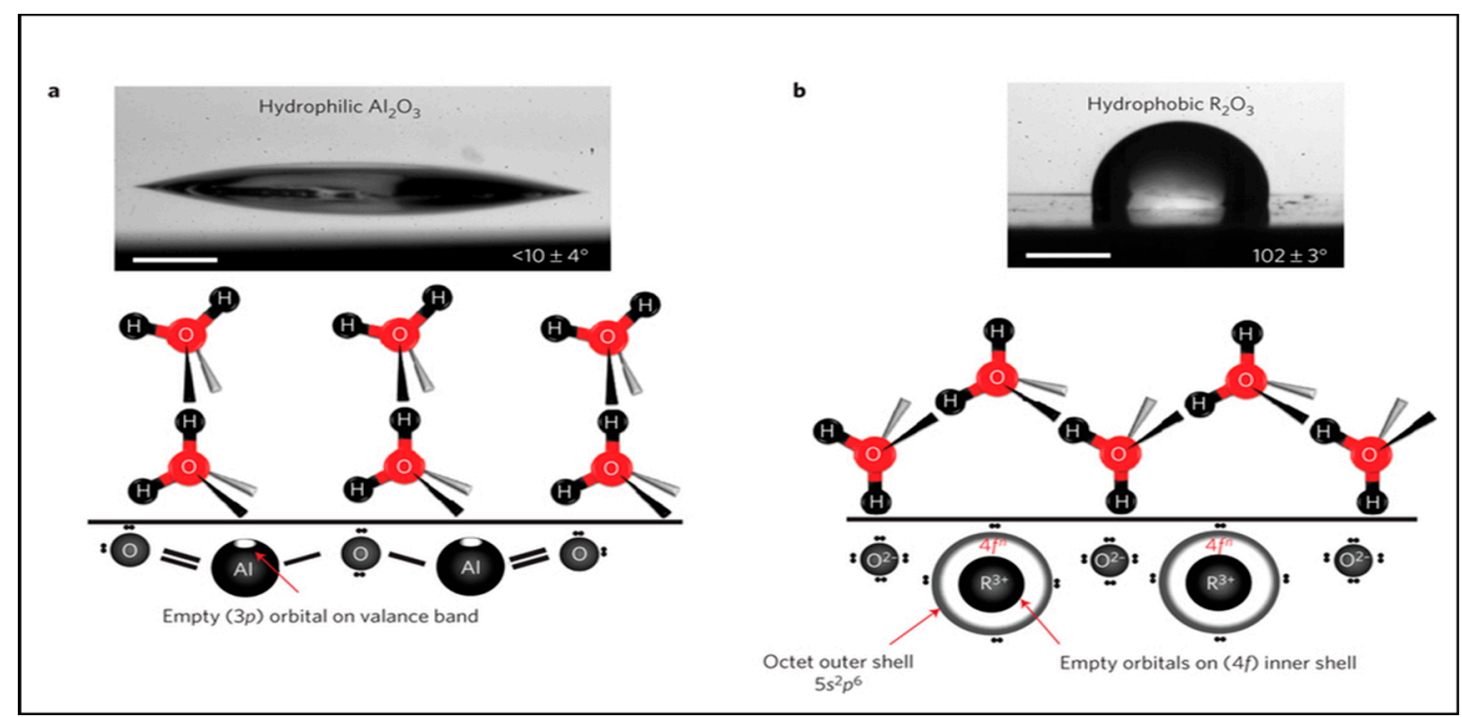

Figure 8. Water molecule orientation on aluminium (metal) oxide (a) and a REO (b) [96]. Reprinted with permission from Ref. [96]. Copyright 2013 Springer.

Heat transfer quantification for REO coatings is limited. In a study by Khan [100], CeO thin film coatings $(\sim 300 \mathrm{~nm})$ were developed by sputtering and tested for $100 \mathrm{~h}$. Results showed sustained 
DWC without deterioration of the structure and enhancement of htc by 10 times $\left(>100 \mathrm{kWh} / \mathrm{m}^{2} \cdot \mathrm{K}\right)$ as compared to htc in the case of FWC $\left(<10 \mathrm{kWh} / \mathrm{m}^{2} \cdot \mathrm{K}\right)$. Recently, Shim et al. [101] developed a CeO coating of less than $200 \mathrm{~nm}$ thickness on $\mathrm{Cu}, \mathrm{Al}$, and steel surfaces by a one-step wet chemical process. This process resulted in the formation of superhydrophobic surfaces with contact angle hysteresis less than $5^{\circ}$. They calculated the heat transfer coefficient by thermal resistance network and using microscopic data from their condensation experiments. The htc for the $\mathrm{CeO}$ coating was found to be 5 times higher than that of silane-treated surfaces. More heat transfer studies need to be carried out concerning coating condensation enhancement, durability, and robustness.

\subsection{Ion Implantation}

Ion implantation is a process in which ions of certain elements are targeted to a solid surface to change its physical, chemical, or electrical properties. Zhang et al. [102] and Zhao et al. [103] were amongst the first to propose ion implantation technology for DWC enhancement. Zhao and Burnside [104] reported 1.8 times higher htc for a $\mathrm{Cr}$ ion-implanted polymer-coated surface. Zhao et al. [103] made four types of surface alloys on $\mathrm{Cu}$ substrate using $\mathrm{H}, \mathrm{He}, \mathrm{Ar}$, and N. Surface energy was affected by both the dose and type of implanted ion. It was noted that the resulting layers were durable. Due to lower coating thickness, thermal resistance was negligible. Resultant surface alloys: $\mathrm{Cu}-\mathrm{Ar}, \mathrm{Cu}-\mathrm{N}, \mathrm{Cu}-\mathrm{He}$, and $\mathrm{Cu}-\mathrm{H}$, showed excellent performance with respect to DWC formation. They compared results from different publications and with their ion-implanted surface and showed its effect to be better than Teflon, silver, and gold; in particular, the heat transfer coefficient was found to be 3 times (max) more than that of noble metals. It was deduced that with ion implantation, the surface changes to an amorphous state. This decreases the modulus of elasticity and hence its surface energy, as the modulus of elasticity is directly related to surface energy, by:

$$
e=\frac{E a}{4 \pi^{2}}
$$

where $e$ is the surface energy, $E$ represents modulus of elasticity, and $a$ is a constant. However, Rausch et al. [105] stated that it is not still very clear as to what characteristics of the ion-implanted surfaces made them feasible for DWC. In another study of ion implantation of $\mathrm{N}^{+}$ions on a titanium surface, the ability to achieve and sustain increased DWC was pointed out [106]. $\mathrm{C}^{+}, \mathrm{O}^{+}, \mathrm{N}^{+}$, and $\mathrm{Ar}^{+}$ ions were implanted in aluminium alloy AL 6951, stainless steel AISI 321, and pure titanium grade 1 using ion beam implanting technology. Their results suggested that particulate precipitates caused inhomogeneity on the surface. This nanoscale roughness and surface chemical inhomogeneity helps in nucleating DWC and sustaining DWC even at increased wettability $[105,107]$. It was supposed that these precipitates were formed by supersaturation of the resultant ion-implanted surface with doping elements. Surface roughness and composition changes are also confirmed by [108] as the cause of DWC, instead of decreasing behavior of wettability, during their study of ion implantation of $\mathrm{N}^{+}$and $\mathrm{Ar}^{+}$on $\mathrm{Al}$ alloy.

Kananeh et al. [109] found a positive effect of steam pressure on DWC, and htc increased by 3.2 times for a $\mathrm{N}^{+}$ion-implanted SS surface was also reported in their study. Ion implantation for condensation has been studied broadly by Leipertz and Froba [49] and Guo et al. [110], who stated that it is mechanically stable. Recently, Kim et al. [111] experimented with $\mathrm{Cr}$ ion implantation on an $\mathrm{Al}$ surface and sustained DWC for over 6 months; the htc was found to be twice that of FWC. Table 2 summarizes experimental work related to DWC enhancement by ion implantation. Diezel et al. [112] and Lukic et al. [113] performed a cost analysis of an ion-implanted condenser for desalination application. They found that the cost for unit distillate can be reduced by up to $35.4 \%$. However, their developed model and assumptions were not verified with experimental data, thereby limiting its usage for industrial applications. Ion implantation showed significant results, but its performance decreased with an increase of subcooling beyond a specific level. Moreover, cost-effectiveness is still a barrier to overcome [62]. 
Table 2. Steam condensation enhancements by ion implantation.

\begin{tabular}{|c|c|c|c|c|c|c|}
\hline Substrate & $\begin{array}{c}\text { Coated } \\
\text { Metal }\end{array}$ & $\begin{array}{l}\text { Coating } \\
\text { Method }\end{array}$ & $\begin{array}{c}\text { Effective } \\
\text { Life of } \\
\text { Coating (h) }\end{array}$ & $\begin{array}{l}\text { Effective } \\
\text { Coating } \\
\text { Thickness } \\
\text { (nm) }\end{array}$ & $\begin{array}{l}\text { Enhancement } \\
\text { in htc }\end{array}$ & Ref. \\
\hline Cu tubes & $\begin{array}{l}\mathrm{N}, \mathrm{Ar}, \mathrm{He}, \mathrm{H}, \\
\quad \text { and } \mathrm{Cr}\end{array}$ & $\begin{array}{c}\text { Ion } \\
\text { implantation }\end{array}$ & - & $\begin{array}{l}\text { Thin layer } \\
(\sim 1 \mathrm{~nm})\end{array}$ & $\begin{array}{l}3 \text { times than } \\
\text { that of noble } \\
\text { metals }\end{array}$ & [103] \\
\hline Cu tubes & $\mathrm{Cr}$ and $\mathrm{O}$ & $\begin{array}{c}\text { Ion } \\
\text { implantation }\end{array}$ & $\begin{array}{c}15,600 \\
\text { (continued) }\end{array}$ & $\begin{array}{l}\text { Thin layer } \\
(\sim 1 \mathrm{~nm})\end{array}$ & - & [110] \\
\hline $\begin{array}{l}\text { polytetrafluoroethylene } \\
\text { (PTFE) coated surfaces }\end{array}$ & $\mathrm{Cr}^{+}$ & $\begin{array}{c}\text { Ion } \\
\text { implantation }\end{array}$ & - & $\begin{array}{l}5 \mu \mathrm{m} \text { PTFE } \\
\text { with } \mathrm{Cr}^{+} \text {ion } \\
\text { implantation }\end{array}$ & 1.8 times & [104] \\
\hline Stainless steel tubes & $\mathrm{N}^{+}$ & $\begin{array}{c}\text { Plasma ion } \\
\text { implantation }\end{array}$ & - & $\begin{array}{l}\text { Thin layer } \\
(\sim 1 \mathrm{~nm})\end{array}$ & 3.2 times & [109] \\
\hline Titanium & $\mathrm{N}^{+}$ & $\begin{array}{c}\text { Ion beam } \\
\text { implantation }\end{array}$ & - & $\begin{array}{l}\text { Thin layer } \\
(\sim 1 \mathrm{~nm})\end{array}$ & 5.5 times & [106] \\
\hline $\mathrm{Al}$ & $\mathrm{Cr}$ & $\begin{array}{c}\text { Plasma ion } \\
\text { implantation }\end{array}$ & - & 9-13 nm & 2 times & [111] \\
\hline
\end{tabular}

\subsection{Polymer Coatings}

For industrial condenser application, polymer-coated tubes seem to be an effective method from both cost and performance aspects [114]. Parylene, silicones, and polytetrafluoroethylene (PTFE) coatings are effective with thin layers to encourage DWC. Durability of polymers is confirmed only for higher thicknesses, but thickness also increases thermal resistance, and hence overcomes advantages of DWC after certain levels. The adhesion between a substrate and thin film is critical for robustness and durability; this problem could be solved with proper binding material/method between the thin polymer layer and substrate to reduce their thermal resistance and increase their heat transfer capacity [62]. Condensation enhancements by polymer coatings are listed in Table 3.

The ability of organic coatings for DWC of steam have been evaluated by researchers $[77,78]$. Marto et al. [78] concluded that organic coatings give 3-6 times better htc than that of FWC, but long-term operation may lead to poor performance. In order to find an effective technique to form polymer films with long-term ability to sustain DWC, Ma et al. [114] studied surface processing conditions. They used an ion beam mixed implantation technique for coating of PTFE films on $\mathrm{Cu}$, brass, stainless steel, and carbon steel tubes with different surface processing techniques. Results showed that conditions of surface processing have a key role in a polymer film's adhesion to the substrate and in variation of its physiochemical properties. However, optimal processing conditions vary between different substrate materials. Depending upon processing conditions, htc for brass substrate with polytetrafluoroethylene (PTFE) polymer film was reported to increase by 1.6-28.6 times, as compared to bare brass surface. Haraguchi et al. [115] concluded that htc can be increased by up to 20 times with polyvinylidene chloride coatings. In another study by Holden et al. [77], dropwise condensation was sustained for more than $22,000 \mathrm{~h}$ of operation, but due to higher coating thickness of $60 \mu \mathrm{m}$, thermal resistance was increased and not much improvement in heat transfer was observed.

Miljkovic et al. [116] used plasma-enhanced physical vapor deposition (PVD) for study of fluoropolymers for DWC. Also, chemical vapor deposition (CVD) of fluoropolymers is an attractive method for thin and robust coating $[117,118]$. Initiated and plasma-enhanced CVD have been recently used to produce very thin polymer coatings $(\sim 40 \mathrm{~nm})$ achieving DWC phenomena [72]. Their mechanical and chemical stability is yet to be studied. A detailed review of applications of polymers for surface DWC was conducted by the authors of [119]. Zhang et al. [64] compared polymers such as polyphenylene sulfide (PPS) and polytetrafluoroethylene (PTFE) with self-assembled micro/nanosilver (SAMS). PPS and PTFE both showed better results with respect to wettability due to their high contact 
angle. Nevertheless, results showed that polymers have poor heat flux compared to SAMS due to their high thermal resistance. Erb and Thelen [92,93] evaluated the cost of thin polymer coatings for DWC and came up with a total cost of around $0.01-0.02 \$ / \mathrm{m}^{2}$. The figures for thin polymer coatings are attractive; however, the durability of thin polymer coatings is still a challenge.

Recently, surface morphologies have been crafted with the combination of hydrophilic and hydrophobic networks using polymer coatings [120,121]. It was found that hybrid surfaces result in enhanced condensation processes as compared to only hydrophilic or hydrophobic surfaces. The enhancement also depends on grid spacing and type of coating. However, the durability of such hybrid networks still needs to be addressed.

Table 3. Steam condensation enhancements by polymer coatings.

\begin{tabular}{|c|c|c|c|c|c|c|}
\hline Substrate & Coated Metal & Coating Method & $\begin{array}{c}\text { Effective } \\
\text { Life of } \\
\text { Coating (h) }\end{array}$ & $\begin{array}{c}\text { Effective } \\
\text { Coating } \\
\text { Thickness (nm) } \\
\end{array}$ & Enhancement in htc & Ref. \\
\hline $\begin{array}{l}\mathrm{Cu}, \mathrm{Cu}-\mathrm{Ni} / \mathrm{Au}, \\
\mathrm{Ti}, \text { brass }\end{array}$ & $\begin{array}{l}\text { Organic coatings (parylene } \\
\text { D/N, fluoroacrylic) }\end{array}$ & - & $>1200$ & $\begin{array}{c}2000-3000 \\
\text { (fluoroacrylic) } \\
500-1000 \\
\text { (parylene N/D) }\end{array}$ & $3-6$ times & {$[78]$} \\
\hline $\begin{array}{c}\text { Cu, brass, } \\
\text { Stainless steel } \\
\text { (SS) and carbon } \\
\text { steel (CS) tubes }\end{array}$ & PTFE & $\begin{array}{l}\text { Ion-beam mixed } \\
\text { implantation }\end{array}$ & $>1000$ & - & 1.6-28.6 times & [114] \\
\hline Cu block & Polyvinylidene chloride & - & $>21,568$ & $50-500$ & 20 times & [115] \\
\hline $\begin{array}{l}\mathrm{Cu} \text { condenser } \\
\text { coil and } \mathrm{Al}\end{array}$ & $\begin{array}{l}\text { Ultrathin copolymer films: } \\
\text { poly-(1H,1H,2H,2H- } \\
\text { perfluorodecyl } \\
\text { acrylate)-co-divinyl } \\
\text { benzene p(PFDA-co-DVB) }\end{array}$ & Initiated CVD & $>48$ & 40 & 7 times & [118] \\
\hline Glass & $\begin{array}{l}\text { Teflon-coated titanium (Ti) } \\
\text { pillars }\end{array}$ & Spray coating & - & 200 (Ti pillars) & - & [120] \\
\hline SS & $\mathrm{PTFE}+\mathrm{SiO}_{2}$ & Spray coating & - & - & $\begin{array}{l}2.7 \text { and } 3.4 \text { times that } \\
\text { of hydrophilic and } \\
\text { hydrophobic surfaces, } \\
\text { respectively }\end{array}$ & [121] \\
\hline Cu substrate & $\begin{array}{l}\text { Needles soldered } \\
\text { superhydrophobic surface }\end{array}$ & $\begin{array}{c}\text { Impaling } \\
\text { superhydrophobic } \\
\text { film }\end{array}$ & $>2.9$ & 200,000 & 4 times & {$[63]$} \\
\hline $\mathrm{Al}, \mathrm{Cu}$ & $\begin{array}{l}\text { Polytetrafluoroethylene } \\
\text { (PTFE) thin films }\end{array}$ & Electrospun & - & 1000 & 1.64 times & [122] \\
\hline $\mathrm{Cu}$ & $\begin{array}{l}\text { fluorosilane polymer } \\
\qquad \text { (EGC-1720) }\end{array}$ & Spin-coating & $>3$ & - & $>2.1$ times & [123] \\
\hline
\end{tabular}

\subsection{Self-Assembled Monolayers (SAMs)}

SAMs are a family of coatings with the ability to form individual-molecule-thickness coatings on a substrate. SAMs have negligible thermal resistance when compared to other hydrophobic coatings such as Teflon $[119,124]$. Chemicals used in such techniques are usually polymers with a reactive functional group on one side. One side of the chemical has the ability to react with the surface and hold it by making chemical bonds, while the other side usually has a function group with low surface energy and hence helps in decreasing wettability, as shown in Figure 9. The ability of SAMs to turn a surface from being hydrophobic to hydrophilic can be suitable for enhancement of condensation phenomena. In addition, these surfaces have impressive applications in biocompatibility, adhesion, and tribology. Due to their highly hydrophobic nature, the surfaces can be used for passive transformation of liquid, even against gravity [17]. SAM coatings show significant performance for condensation enhancement. Some of the notable work related to dropwise condensation by SAMs are listed in Table 4. 


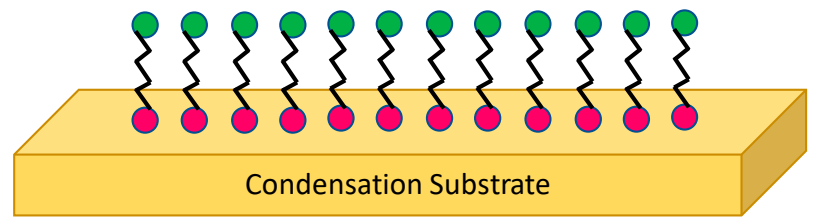

Figure 9. Working principal of self-assembled monolayers (SAMs) showing the fundamental blocks.

Table 4. Steam condensation enhancements by SAM coatings.

\begin{tabular}{ccccc}
\hline Substrate & Coated Metal & $\begin{array}{c}\text { Effective Life } \\
\text { of Coating (h) }\end{array}$ & $\begin{array}{c}\text { Enhancement } \\
\text { in htc }\end{array}$ & Ref. \\
\hline $\mathrm{Cu}$ and $\mathrm{Au}$ & heptadecafluoro-1-decanethiol & $>6480$ & - & {$[17]$} \\
\hline $\mathrm{Cu}$ and $\mathrm{Cu}-\mathrm{Ni}$ & hexadecylthiol & - & 5 times & {$[73]$} \\
\hline $\mathrm{Cu}$ & n-octadecanethiol & - & $1.7-2.1$ times & {$[127]$} \\
\hline $\mathrm{Cu}$ & $\begin{array}{c}\text { stearic acid solution and } \\
\text { n-octadecyl mercaptan solution }\end{array}$ & $>2600$ & 1.8 times & {$[126]$} \\
\hline $\mathrm{Cu}$ & $\begin{array}{c}\text { aqueous silver nitrate solution and } \\
\text { 1-dodecanethiol was spray-coated }\end{array}$ & $>500$ & 4.18 times & {$[64]$} \\
\hline $\mathrm{Cu}$ tube & docosanoic acid & - & 10 times & {$[125]$} \\
\hline
\end{tabular}

Das et al. [73] studied the application of SAM coating of hexadecylthiol on copper, copper-nickel alloy, and gold-sputtered aluminum surfaces. The performance enhancement of $\mathrm{Cu}$ and $\mathrm{Cu}-\mathrm{Ni}$ alloy was noted to be superior to that of the Au-sputtered Al surface. The results showed that heat transfer for $\mathrm{Cu}, \mathrm{Cu}-\mathrm{Ni}$ alloy, and $\mathrm{Au}$-sputtered $\mathrm{Al}$ surfaces was increased by 5, 5, and 4 times, respectively, compared to their respective filmwise condensation. There are similar studies in the literature which have proved the enhancement of condensation with the application of SAMs on substrates [125-127]. These studies show that SAMs have strong bonds with the substrate surfaces and hence the coating is more durable and has a long lifetime. Bonner et al. [17] studied the durability/lifetime of heptadecafluoro-1-decanethiol SAM coatings with sulfur as the functional group on $\mathrm{Cu}$ and gold substrates. The result showed that both the coatings continued to perform over 9 months. SAM coatings were also compared with other type of coatings; the durability and condensation htc of SAMs was reported to be higher than polymer coatings such as polyphenylene sulfide (PPS) and polytetrafluoroethylene (PTFE) in [64].

Since the coating thicknesses of SAMs are in the order of $\sim 1 \mathrm{~nm}$, this means that htc will decrease sharply as the SAM coating deteriorates. Thus, the need for SAM coating robustness and durability still need to be enhanced for industrial-based applications. Silanes and thiols are two of the most commonly used SAM coatings. Silanes are more stable than thiols, which limits the use of thiols on the laboratory scale [128]. In order to overcome deterioration, self-healing coatings have been established, which will increase the effective lifetime of coatings $[129,130]$.

\subsection{Lubricant-Infused Surfaces (LIS)}

Drops on the superhydrophobic surfaces remain in the Cassie state and easily slide off/detach from the surface. However, the nucleation of droplets inside the pores of these surfaces make them poor in performance for condensation. In order to solve this problem of superhydrophobic surfaces, lubricant-infused surfaces (LIS) were developed by coating lubricant over them [62]. These surfaces help to enhance droplet mobility compared to uncoated superhydrophobic surfaces due to decrease in its pinning behavior to the substrate [131]. The advantages of LIS include self-healing [132], self-cleaning [133], antifouling [134], and omniphobic [132,135] properties. 
Quan et al. [136] developed oil-infused nanograss on copper surface and found htc to increase by $50 \%$ as compared to the bare surface. The increment was due to sustained DWC and rapid droplet removal from the surface. In another study [137], droplet size distribution was measured and it was concluded that droplet size variation is independent of lubricant viscosities. As the temperature changes, thermophysical properties of fluids also change. Thus, at elevated temperature, surface tension of water drops and htc for hydrophobic surfaces decreases. However, LIS was found to sustain DWC at higher temperatures [138]. Xiao et al. [72] introduced a biphilic functional layer to reduce interfacial energy between condensate and lubricant; this increases nucleation droplet density, and hence htc. They found that the htc achieved was doubled as compared to the normal DWC heat transfer coefficient.

Lately, Preston et al. [139] experimented with the condensation of water and toluene and found that htc was 4.5 times higher with the implementation of LIS. Nevertheless, they noticed that with the passage of time, condensation mode changes from DWC to FWC due to lubricant depletion. LIS can be effective for condensation enhancement, but the longevity of these surfaces in terms of lubricant durability stills need to be improved. In addition, in applications where quality of condensate is critical, such as desalination, the removal of these lubricants and contaminating condensate makes its practical applications inadequate.

\subsection{Graphene, Carbon Nanotubes (CNT), and Nanostructured Surfaces}

Graphene, carbon nanotubes, and other nanostructured surfaces are getting researchers' attention for various heat transfer applications. Application of these coatings for condensation enhancements are listed in Table 5. Graphene has received remarkable attention for its wide range of applications from electronic devices to membrane desalination and many others under exploration during the last decade [140,141]. Similarly, its applicability for DWC was explored by Preston et al. [65]. They observed that with a single-layer thin graphene coating on $99.99 \%$ pure copper substrate, htc enhancement for condensation was 4 times greater than the corresponding sustained FWC and DWC, as shown in Figure 10. They used both low-pressure CVD and atmospheric-pressure CVD for graphene coating, and both samples showed enhanced results as compared to the uncoated one. Furthermore, the durability of both coated surfaces was experimentally observed, and no sign of degradation was observed during a 2-week period. Graphene coatings also offer a potential solution to common challenges in practical applications of DWC coating on an industrial scale, such as chemical unitability, robustness, or high thermal resistivity.
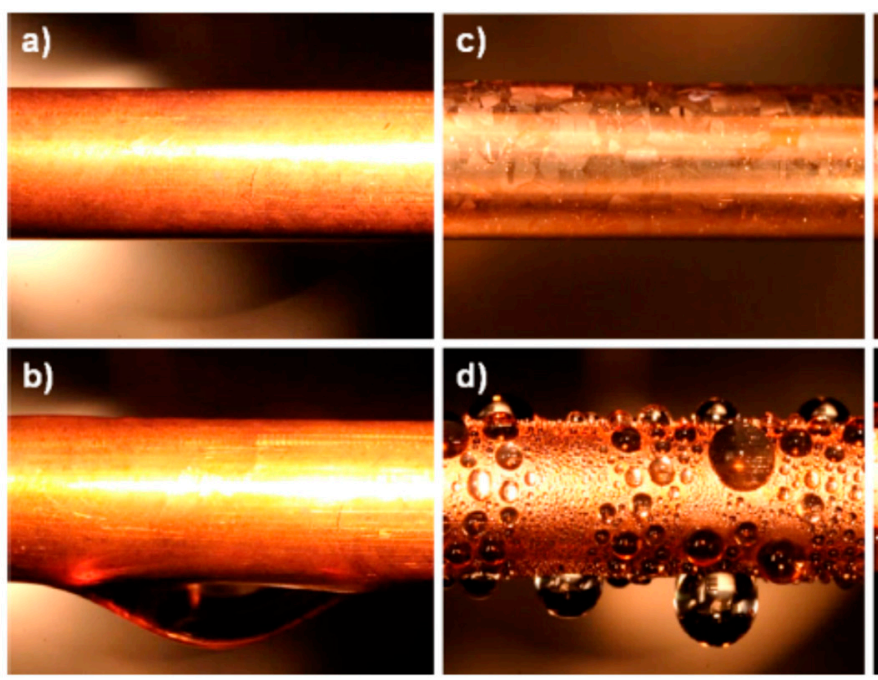

Figure 10. Cu tube (a) under vacuum and (b) showing FWC; graphene-coated Cu tube shows DWC with $(\mathbf{c}, \mathbf{d})$ low-pressure and $(\mathbf{e}, \mathbf{f})$ atmospheric-pressure CVD coatings [65]. Reprinted with permission from Ref. [65]. Copyright 2015 ACS Publications.

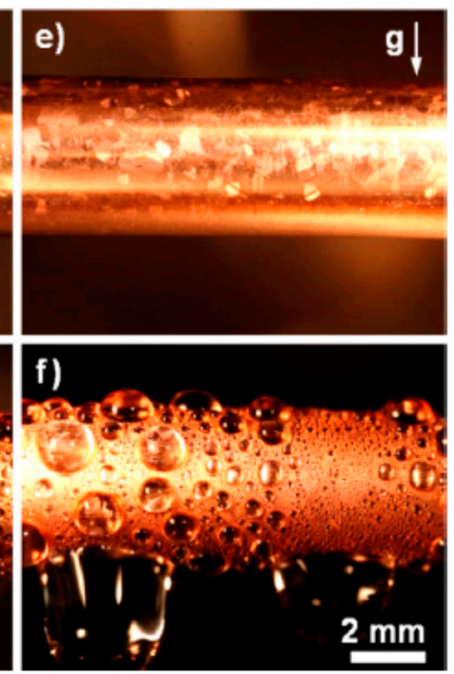


Like graphene, the unique thermal, mechanical, and electrical properties of carbon nanotubes (CNT) make them a point of interest in many applications. CNTs can be developed in multiwalled or single-walled forms. Thermal conductivity of multiwalled CNT was reported to be up to 3000 $\mathrm{W} / \mathrm{m} \cdot \mathrm{K}$ at room temperature by [142]. High thermal conductivity and hydrophobic nature of CNT also make it remarkable for condensation enhancement application. However, unlike the wide boiling applications of CNT, where CNT coatings have been tested widely, its study regarding condensation phenomena is limited. Chen et al. [143] reported a CNT coating using a $\mathrm{Cr}-\mathrm{Ni}$ layer as catalyst. They developed superhydrophobic surfaces resembling lotus leaves by depositing CNTs. It was found that superhydrophobicity for a hexadecanethiol-coated surface is more durable than for a CNT-coated surface for steam condensation application. Kim et al. [144] studied multiwalled CNT and Fe coatings on steel substrate; the objective was to find optimal conditions for powder composition and sintering for maximum enhancement of condensation heat transfer. Increase in CNT volume showed an increase in contact angle, and optimum conditions were noted with $10 \%$ of CNT composite with 1.6 times enhancement in htc. Diamond-like carbon (DLC) film coating is a nanocomposite coating with unique properties of high hardness and corrosion rate and low friction, and is one of the methods that have been developed and tested for DWC of steam on metallic surfaces [145]. DLC coatings are mechanically stable, hydrophobic, chemically inert, and highly resistant to solvents, alkalis, and acids. However, they give extra resistance to heat transfer, which can be overcome by ion implantation [102]. The cost estimation for scalable graphene by CVD has been calculated to be $11.98 \$ / \mathrm{m}^{2}$, including gas and electricity usage for lab-scale production $[65,146]$. The estimated cost is very high as compared to noble metal, REO, and polymer coatings, but it is expected that the cost may reduce significantly with coating application optimization and large-scale production.

Among emerging materials such as graphene and $\mathrm{CNT}$, carbon fibers $(\mathrm{CFs})$ also exhibit favorable properties, such as light weight, high porosity, and strength, which make it valuable for many applications including condensation. Ko et al. [147] produced nanostructures with CFs to achieve superhydrophobic surfaces for condensation study of super-saturated vapors. They reported contact angle hysteresis to decrease from $71^{\circ}$ to $5^{\circ}$ and htc enhancement due to resultant dropwise condensation. Zhao et al. [148] deposited monomolecular layers of barium stearate on copper surface, and 30 times higher htc as compared to bare surface was reported. The performance was evaluated for few weeks and it was expected that these monomolecular layers might sustain DWC for a long time.

With the potential of sustaining DWC using nanostructuring, researchers have been focusing more on understanding and implementing nanostructures in the past few years [149-151]. Park et al. [152] investigated slippery asymmetric bumps for condensation. They reported six times higher growth rate, higher turnover rate, and faster onset with improved collection of water volume. Bahrami and Saffari [153] theoretically investigated droplet distribution and DWC performance for micro-nanostructured surfaces. The overall heat transfer for vertical tubes was found to be 5 times higher than that of horizontal tubes in some cases. In another similar study by Chen [154], optimization of two-tier roughness of nanostructures was carried out and it was highlighted that the second-tier roughness of a nanostructure can diminish the dissipation and pinning of condensate at the contact line. For durability test, Parin et al. [155] conducted experiments on a silane-based nanostructured surface and analyzed condensation processes. They found that htc can be enhanced by up to 8 times of the FWC htc. However, as time passes, condensation mode changes from DWC to hybrid and FWC, hence decreasing htc was observed. Experiments were conducted for a maximum of one hour and htc dropped during this period, which shows that robust nanostructured surfaces are required in order to sustain DWC. Zhu et al. [156] reported 125\% enhancement in dropwise condensation heat transfer by growing cluster ribbed nano needles, as shown in Figure 11.

In a related study by Xie et al. [157], silane-based nanograssed surface durability was tested for one week. During this period, the htc dropped on the third day, as the drop dynamics change from rolling/jumping to sliding mode, and beyond the third day htc was stabilized. The long-term operation changed surface roughness and morphology. However, emerging surface coatings may be 
a promising technology for obtaining DWC, but a lot of work still needs to be carried out for their durability and robustness.

Table 5. Condensation enhancements by graphene, carbon nanotubes (CNTs), and other nanostructured surfaces.

\begin{tabular}{|c|c|c|c|c|c|c|}
\hline Substrate & Coated Metal & Coating Method & Condensate & $\begin{array}{c}\text { Effective } \\
\text { Life of } \\
\text { Coating (h) }\end{array}$ & $\begin{array}{l}\text { Enhancement in } \\
\text { htc }\end{array}$ & Ref. \\
\hline $\mathrm{Cu}$ & Graphene & $\begin{array}{c}\text { Low- and } \\
\text { atmospheric-pressure CVD }\end{array}$ & Steam & $>336$ & 4 times & [65] \\
\hline $\mathrm{Si}$ & CNT with $\mathrm{Cr}-\mathrm{Ni}$ as catalyst & Plasma-enhanced CVD & Steam & - & - & [143] \\
\hline $\begin{array}{l}\text { Carbon } \\
\text { steel }\end{array}$ & $\begin{array}{c}\text { Composite of multiwalled } \\
\text { CNTs and Fe }\end{array}$ & $\begin{array}{l}\text { Electrostatic spraying followed } \\
\text { by sintering at } 900^{\circ} \mathrm{C}\end{array}$ & R-134a & - & 1.6 times & [144] \\
\hline $\mathrm{Cu}$ & $\begin{array}{l}\text { Barium stearate } \\
\text { monomolecular film }\end{array}$ & $\begin{array}{c}\text { Langmuir-Blodgett } \\
\text { (L-B) built-up film technology }\end{array}$ & Steam & - & 30 times & [148] \\
\hline $\mathrm{Cu}$ & $\begin{array}{c}1 \mathrm{H}, 1 \mathrm{H}, 2 \mathrm{H}, 2 \mathrm{H}- \\
\text { perfluorooctyltriethoxysilane }\end{array}$ & $\begin{array}{l}\text { Wet oxidation }+ \\
\text { self-organization of } \\
\text { macromolecules }\end{array}$ & Steam & $>168$ & $\begin{array}{l}\text { Decreased on 3rd } \\
\text { day }\end{array}$ & [157] \\
\hline $\mathrm{Al}$ & $\begin{array}{l}\text { Trichloro }(1 \mathrm{H}, 1 \mathrm{H}, 2 \mathrm{H}, 2 \mathrm{H}- \\
\text { perfluorooctyl) silane }\end{array}$ & Spin-coated & Steam & $\sim 1$ & 8 times & [155] \\
\hline $\mathrm{Al}$ & flurorosilane film & Etching and flurorosilane film & Steam & - & 4 times & [158] \\
\hline $\mathrm{Cu}$ & $\begin{array}{l}\text { Cu micro-nanostructured } \\
\text { surface }\end{array}$ & $\begin{array}{l}\text { Spin coating followed by } \\
\text { soft-baking at } 100{ }^{\circ} \mathrm{C}\end{array}$ & Humid air & - & $\begin{array}{l}\text { Droplet growth was } \\
\text { compared with only } \\
\text { nanocoated surface }\end{array}$ & [159] \\
\hline $\mathrm{Cu}$ & Nickle nanocone film & In situ growth & Steam & - & $89 \%$ & [160] \\
\hline $\mathrm{Cu}$ & Copper nanowires & $\begin{array}{l}\text { porous anodic alumina } \\
\text { template-assisted } \\
\text { electrodeposition }\end{array}$ & Steam & - & $\begin{array}{l}100 \% \text { higher heat } \\
\text { flux }\end{array}$ & [161] \\
\hline
\end{tabular}

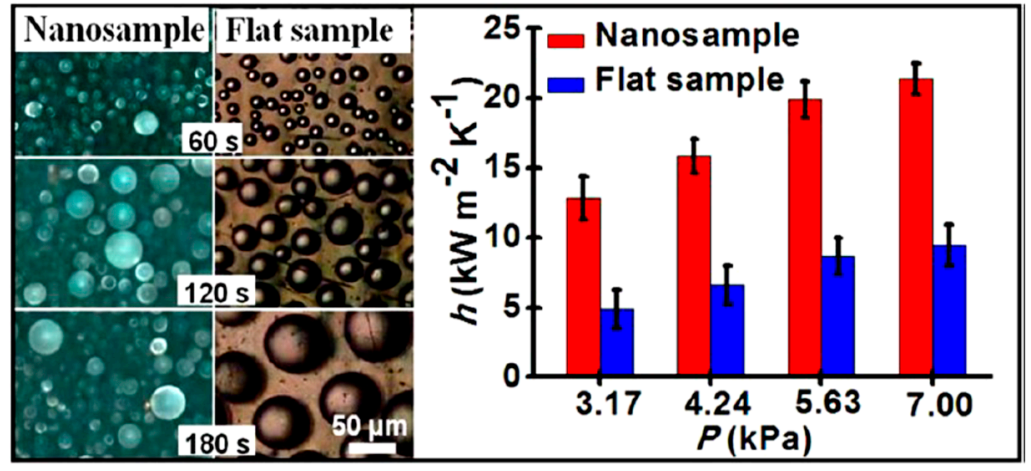

Figure 11. Visual comparison of dropwise condensation and increase in heat transfer coefficient of the flat sample and nanosample coated $\mathrm{Cu}$ substrate [156].

\subsection{Porous Coatings}

Porous coatings have an ability to increase overall surface area, which can make the condensation process quick. However, the ability to trap liquid inside has a negative effect on the overall heat transfer from gas phase to the substrate. Unlike boiling, this property of porous coatings makes them less feasible for condensation processes. The liquid entrainment problem has been handled by liquid infusion, and these surfaces are termed as slippery liquid infused porous surfaces (SLIPS) [165]. The disadvantage of SLIPS are their durability; after a certain time, liquid infusion diminishes, and due to 
condensate pinning, htc decreases [166]. Attempts have been made to develop microporous surfaces along with SAMs $[167,168]$. It was found that heat transfer coefficient greatly depends on microporous powder diameter. As the diameter decreases, htc increases; for a $4-\mu \mathrm{m}$ diameter, $23 \%$ htc increment was reported as compared to bare surface [168]. However, the improvement is low as compared to other coating techniques.

\section{Discussion and Challenges}

The heat transfer coefficient of DWC is higher than FWC by several times [155,157], while the overall heat transfer coefficient can be augmented by three times [114,146]. Therefore, obtaining stable DWC mode will improve overall performance, but stability of DWC mode depends on several factors such as wettability state, hydrophobicity, condensate surface tension, contact angle hysteresis, and droplet departure/removal. These required properties can be achieved by micro-nanoscale surface coating implementation. The contact angle can be tailored by microscale roughness, whereas contact angle hysteresis can be reduced by nanoscale roughness [169]. However, robustness, cost, durability, and application methods are some hurdles that need to be overcome for industrial application [24,27]. The degradation of coatings under transient conditions usually results in FWC within weeks or months. The advantages and disadvantages associated with different types of coatings are presented in Table 6 .

Table 6. Advantages and disadvantages associated with different types of surface coatings.

\begin{tabular}{|c|c|c|}
\hline Surface Coating Technique & Advantages & Disadvantages \\
\hline Noble metals & $\begin{array}{l}\text { DWC increases due to the absorption of } \\
\text { impurities and hydrocarbons. }\end{array}$ & $\begin{array}{l}\text { High price of the material limits its } \\
\text { practical application. }\end{array}$ \\
\hline REOs & $\begin{array}{l}\text { Possesses hydrophobic nature, which } \\
\text { promotes DWC. }\end{array}$ & $\begin{array}{l}\text { Low thermal conductivity. } \\
\text { Lack of heat transfer studies. }\end{array}$ \\
\hline Ion implantation & $\begin{array}{l}\text { Enhances heat transfer capability at low } \\
\text { subcooling. Low-temperature process. }\end{array}$ & $\begin{array}{l}\text { Performance decreases with increase of } \\
\text { subcooling after a particular level. } \\
\text { Expensive, which limits its scalability. }\end{array}$ \\
\hline Polymer coating & $\begin{array}{l}\text { Effective method from both cost and } \\
\text { performance aspects. Increases DWC } \\
\text { and htc. }\end{array}$ & $\begin{array}{l}\text { Durability of thin coating needs to be } \\
\text { addressed. }\end{array}$ \\
\hline SAMs & Negligible thermal resistance. High htc. & $\begin{array}{c}\text { Robustness and durability for SAM needs } \\
\text { to be improved for industrial-based } \\
\text { applications. }\end{array}$ \\
\hline $\begin{array}{l}\text { Lubricant-infused surfaces } \\
\text { (LIS) }\end{array}$ & $\begin{array}{l}\text { Effective for condensation enhancement. } \\
\text { Advantages include self-healing, } \\
\text { self-cleaning, antifouling, and } \\
\text { omniphobic properties. }\end{array}$ & $\begin{array}{l}\text { The removal of lubricants and } \\
\text { contaminating condensate makes practical } \\
\text { application inadequate. }\end{array}$ \\
\hline Nanostructured Surfaces & $\begin{array}{l}\text { htc enhancement for condensation. } \\
\text { Offers chemical unitability, robustness, } \\
\text { and low thermal resistivity. }\end{array}$ & $\begin{array}{l}\text { Long-term durability issues. } \\
\text { Limits scalability at the industrial level. }\end{array}$ \\
\hline Porous coating & $\begin{array}{l}\text { Increases overall surface area. } \\
\text { Quick condensation process. }\end{array}$ & $\begin{array}{l}\text { Liquid trapped has a negative effect on the } \\
\text { overall heat transfer from gas phase to the } \\
\text { substrate. Unlike boiling, this property } \\
\text { makes it less feasible for condensation. }\end{array}$ \\
\hline
\end{tabular}

Despite the past nine decades of efforts in research and development on DWC enhancement, the industrial implementation studies are very limited. This is due to the lack of fundamental understanding, lower stability, and required maintenance of coatings [170]. In the 1950s, organic substances were used with steam to enhance DWC in a marine condenser and DWC was sustained for two years [171]. The heat transfer measurements were not taken and organic compounds were found to be unsuitable for the application [171]. Another commercial example includes an ion-implanted condenser, which was used for the Dalian power plant in China [104]. The condenser was operated successfully for four years; the measured htc was more than twice those of normal values and the 
number of tubes was reduced to half than that required [172]. Some of the existing challenges and room for improvements in implementing surface-coated condensers at the industrial scale are as follows:

- Erb and Thelen [92,93] reported a total cost of 0.07-0.20 \$/ $\mathrm{m}^{2}$ for electrodeposited noble metals and $0.01-0.02 \$ / \mathrm{m}^{2}$ using their experimental data. In addition, Preston et al. [65] also used experimental data and calculated the cost for scalable graphene as $11.98 \$ / \mathrm{m}^{2}$. Diezel et al. [112] used simulations to evaluate ion-implanted condenser cost reduction, which was around $35.4 \%$. Although different studies accounted for cost analysis, they are inconclusive as the techno-economic comparison depends on several interdependent factors. Detailed economic analysis is needed for accurate cost estimation and to be used for the comparison of different coating techniques. In addition, novel manufacturing techniques need to be studied to achieve cost-effectiveness of these coatings.

- Toxicity and compatibility with condensing medium should be investigated for industrial applications [171]. For the LIS coating system, the lubricant may be deteriorated with condensing steam and affect steam quality.

- Kim et al. [144] studied multiwalled CNT and Fe coatings for refrigerant R-134a condensation, which is widely used in the refrigeration industry. However, most of the condensation experiments in the literature are for steam and at low pressure and temperature. For higher pressure and temperature, experiments need to be carried in order to facilitate the studies for different condensing liquids as per industrial applications.

- Although researchers have developed different numerical models [31-34] in order to understand PCHT fundamentals at the micro/nanoscale, accurate and generic theoretical models are lacking in the literature. More insight into droplet nucleation is needed, as it is crucial for sustained DWC.

- Standardized lifetime test needs to be developed for performance and lifetime measurement to make fair comparison of these coating techniques. The long-term experimental data is required that can provide information on the durability, performance, and shortcomings of surface coating techniques. These kinds of experiments can help in identifying the root causes of physical mechanisms of failures of these surfaces and in implementing surface-coated condenser at the industrial scale. In addition, corrosion, erosion, and adhesion problems of micro-nano surface coatings need to be addressed.

- For the past few years, more emphasis has been given to nanostructured coatings, CNT, and graphene coatings. As these types of coatings are new and in development stages, as compared to other coating techniques, certain issues need to be resolved for their practical application. The main drawbacks of these coatings are durability and scalability. Furthermore, to ensure droplet-jumping phenomenon and sustained DWC, controlled methods for nanostructured coating needs to be considered.

- Industrial applications are not reported in the literature for structured hydrophobic coatings. Further investigation is required for deterioration, erosion, and maintenance requirements for this type of coating. In addition, projected area is normally used for heat transfer calculations rather than actual surface area, which may lead to inaccurate and overestimated results.

\section{Conclusions}

Micro/nanomanufacturing technologies give a wide range of possibilities for surface modification and hence performance enhancement for condensation processes. The idea of the enhancement of heat transfer performance through surface modification or coatings is not new, but the development of surface modification technologies, especially micro/nanoscale fabrication and wettability modification of coatings (from hydrophilic to hydrophobic), have provided a wide range of possibilities for their usage in practical applications. In this survey, available coatings at the micro-nanoscale are discussed and evaluated, and existing challenges with respect to their implementation are highlighted. Some of the main highlights are as follows: 
- Ion implantation and noble metals offer better hydrophobicity, but the cost of developing coatings is high and their hydrophobicity is not stable as compared to polymer coatings.

- REOs' cost is less than $1 \%$ of noble metal coatings and thermal conductivity is approximately 50 times higher than fluoropolymers. Nevertheless, the heat transfer studies on REOs are limited, so more in-depth analysis is needed before commercialization.

- Polymer coatings can provide stable DWC mode and durability if the coating's thickness is in the order of microns. Nevertheless, higher thickness leads to increased thermal resistance. On the contrary, low coating thickness can be effective and may achieve 10 times higher htc. The challenges associated with thin coatings are uniformity and durability.

- SAM coatings' thickness is very low $(\sim 10 \mathrm{~nm})$ and uniformity can be maintained; the thermal resistance is negligible, which is beneficial for heat transfer. Despite these favorable properties, its thermal stability in hot streams limits its practical implementation.

- LIS can be an effective alternative for obtaining stable DWC mode, but with the passage of time, DWC mode changes to hybrid/FWC mode due to lubricant deterioration. The lubricant durability still needs to be improved. In addition, in applications where quality of condensate is critical, the removal of these lubricants and contaminating condensate makes its practical applications inadequate.

- Emerging surface coatings such as CNTs, CF, graphene, and nanostructured surfaces can be promising alternatives for stable DWC mode, but the development of these coatings is in early stages and needs maturity for its real-world implementations.

- Hybridization of different techniques should be applied to study the possibilities of enhanced heat transfer results, such as combination of nanoparticles and structured porous coatings using durable materials, coating processes, and combination of structured porous and hydrophilic and hydrophobic coatings.

- Despite the significant improvements in condensation heat transfer performance with newly developed coating materials and processes, their industrial application is still not realized practically.

Author Contributions: Conceptualization, S.A.K. and M.K.; methodology, M.K.; formal analysis, S.A.K., F.T. and A.A.B.B.; investigation, S.A.K.; resources, S.A.K., F.T. and A.A.B.B.; writing-original draft preparation, S.A.K.; writing-review and editing, F.T., A.A.B.B. and M.K.; visualization, F.T. and A.A.B.B.; supervision, M.K.; project administration, M.K.; funding acquisition, S.A.K.

Funding: The publication of this article was funded by the Qatar National Library (QNL).

Acknowledgments: The authors acknowledge the support provided by the Hamad Bin Khalifa University, Qatar Foundation (210003980, 210004792, 210003976).

Conflicts of Interest: The authors declare no conflict of interest.

\section{Nomenclature}

$\begin{array}{ll}A & \text { Heat transfer area } \\ \text { a } & \text { Constant } \\ \text { C } & \text { Cassie state } \\ \text { CAPEX } & \text { Capital expenditure } \\ \text { CF } & \text { Carbon fiber } \\ \text { CHF } & \text { Critical Heat Flux }\left(\mathrm{W} / \mathrm{m}^{2}\right) \\ \text { CNT } & \text { Carbon nanotubes } \\ \text { CVD } & \text { Chemical vapor deposition } \\ \text { DLC } & \text { Diamond-like carbon } \\ \text { DWC } & \text { Dropwise condensation } \\ \text { E } & \text { Modulus of elasticity }\left(\mathrm{N} / \mathrm{m}^{2}\right) \\ e & \text { Surface energy } \\ \text { FWC } & \text { Filmwise condensation } \\ g & \text { Acceleration due to gravity }\left(\mathrm{m} / \mathrm{s}^{2}\right)\end{array}$




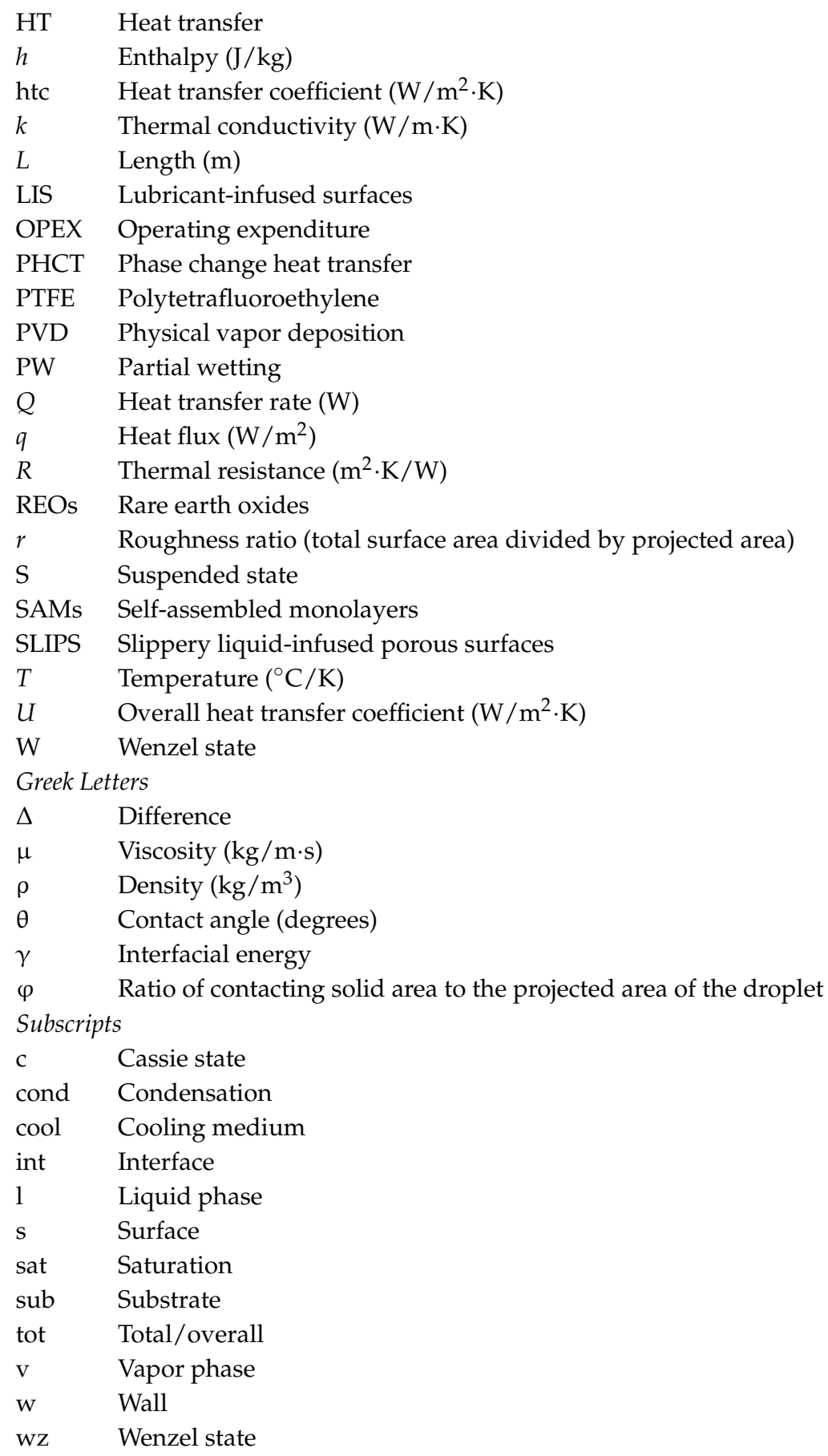

\section{References}

1. Khan, S.; Atieh, M.; Koç, M. Micro-nano scale surface coating for nucleate boiling heat transfer: A critical review. Energies 2018, 11, 3189. [CrossRef]

2. Chen, X.; Wu, J.; Ma, R.; Hua, M.; Koratkar, N.; Yao, S.; Wang, Z. Nanograssed micropyramidal architectures for continuous dropwise condensation. Adv. Funct. Mater. 2011, 21, 4617-4623. [CrossRef]

3. Khan, S.A.; Bicer, Y.; Koç, M. Design and analysis of a multigeneration system with concentrating photovoltaic thermal $(\mathrm{CPV} / \mathrm{T})$ and hydrogen storage. Int. J. Hydrog. Energy 2018, in press. [CrossRef]

4. Khawaji, A.D.; Kutubkhanah, I.K.; Wie, J.-M. Advances in seawater desalination technologies. Desalination 2008, 221, 47-69. [CrossRef] 
5. Rykaczewski, K.; Scott, J.H.J.; Rajauria, S.; Chinn, J.; Chinn, A.M.; Jones, W. Three dimensional aspects of droplet coalescence during dropwise condensation on superhydrophobic surfaces. Soft Matter 2011, 7, 8749. [CrossRef]

6. Human Development Report 2006; United Nations Development Programme: New York, NY, USA, 2006.

7. World Energy Outlook 2010; International Energy Agency: Paris, France, 2010.

8. Khan, Z.; Shah, R.; Islam, S.; Jan, H.; Jan, B.; Rasheed, H.-U.; Khan, A. MHD flow and heat transfer analysis in the wire coating process using elastic-viscous. Coatings 2017, 7, 15. [CrossRef]

9. Lara, J.R.; Holtzapple, M.T. Experimental investigation of dropwise condensation on hydrophobic heat exchangers part I: Dimpled-sheets. Desalination 2011, 278, 165-172. [CrossRef]

10. Wi, Y.; Kim, J.; Lee, J.; Lee, J. Optimal patterned wettability for microchannel flow boiling using the lattice Boltzmann method. Coatings 2018, 8, 288. [CrossRef]

11. Bonner, R.W. Dropwise condensation on surfaces with graded hydrophobicity. In Proceedings of the ASME 2009 Heat Transfer Summer Conference collocated with the InterPACK09 and 3rd Energy Sustainability Conferences, San Francisco, CA, USA, 19-23 July 2009; pp. 491-495.

12. Wang, Q.; Xie, H.; Hu, Z.; Liu, C. The impact of the electric field on surface condensation of water vapor: Insight from molecular dynamics simulation. Nanomaterials 2019, 9, 64. [CrossRef]

13. Islam, A.; Sun, A.; Sepehrnoori, K. An efficient computational scheme for two-phase steam condensation in the presence of $\mathrm{CO}_{2}$ for wellbore and long-distance flow. ChemEngineering 2019, 3, 4. [CrossRef]

14. Mabrouk, A.; Abotaleb, A.; Tahir, F.; Darwish, M.; Aini, R.; Koc, M.; Abdelrashid, A. High performance MED desalination plants Part I: Novel design MED evaporator. In Proceedings of the IDA 2017 World Congress on Water Reuse and Desalination and Water Science, Sao Paulo, Brazil, 15-20 October 2017.

15. Tahir, F.; Atif, M.; Antar, M.A. The effect of fouling on performance and design aspects of multiple-effect desalination systems. In Recent Progress in Desalination, Environmental and Marine Outfall Systems; Baawain, M.S., Choudri, B.S., Ahmed, M., Purnama, A., Eds.; Springer International Publishing: New York, NY, USA, 2015; pp. 35-52.

16. Mabrouk, A.; Abotaleb, A.; Abdelrehim, H.; Tahir, F.; Koc, M.; Abdelrashid, A.; Nasralla, A. High performance MED desalination plants, Part II: Novel integration MED-absorption vapor compression. In Proceedings of the IDA 2017 World Congress on Water Reuse and Desalination and Water Science, Sao Paulo, Brazil, 15-20 October 2017.

17. Bonner, R.W., III. Dropwise condensation life testing of self assembled monolayers. In Proceedings of the 2010 14th International Heat Transfer Conference, Washington, DC, USA, 8-13 August 2010.

18. Phadnis, A.; Rykaczewski, K. Dropwise condensation on soft hydrophobic coatings. Langmuir 2017, 33, 12095-12101. [CrossRef] [PubMed]

19. Manglik, R.M. Heat transfer enhancement. In Heat Transfer Handbook; Bejan, A., Kraus, A.D., Eds.; Wiley: Hoboken, NJ, USA, 2003.

20. Ullah, A.; Alzahrani, E.; Shah, Z.; Ayaz, M.; Islam, S. Nanofluids thin film flow of Reiner-Philippoff fluid over an unstable stretching surface with Brownian motion and thermophoresis effects. Coatings 2018, 9, 21. [CrossRef]

21. Zhao, X.; Chen, X.; Zhang, L.; Liu, Q.; Wang, Y.; Zhang, W.; Zheng, J. Preparation of nano-hydroxyapatite coated carbon nanotube reinforced hydroxyapatite composites. Coatings 2018, 8, 357. [CrossRef]

22. Zarei, S.; Talesh Bahrami, H.R.; Saffari, H. Effects of geometry and dimension of micro/nano-structures on the heat transfer in dropwise condensation: A theoretical study. Appl. Therm. Eng. 2018, 137, 440-450. [CrossRef]

23. Attinger, D.; Frankiewicz, C.; Betz, A.R.; Schutzius, T.M.; Ganguly, R.; Das, A.; Kim, C.; Megaridis, C.M. Surface engineering for phase change heat transfer: A review. MRS Energy Sustain. 2014, 1. [CrossRef]

24. Kim, D.E.; Yu, D.I.; Jerng, D.W.; Kim, M.H.; Ahn, H.S. Review of boiling heat transfer enhancement on micro/nanostructured surfaces. Exp. Therm. Fluid Sci. 2015, 66, 173-196. [CrossRef]

25. Sezer, N.; Koç, M. Oxidative acid treatment of carbon nanotubes. Surf. Interfaces 2019, 14, 1-8. [CrossRef]

26. Sezer, N.; Koç, M. Stabilization of the aqueous dispersion of carbon nanotubes using different approaches. Therm. Sci. Eng. Prog. 2018, 8, 411-417. [CrossRef]

27. Wu, J.M.; Zhao, J. A review of nanofluid heat transfer and critical heat flux enhancement-Research gap to engineering application. Prog. Nucl. Energy 2013, 66, 13-24. [CrossRef] 
28. Bisetto, A.; Torresin, D.; Tiwari, M.K.; Del Col, D.; Poulikakos, D. Dropwise condensation on superhydrophobic nanostructured surfaces: Literature review and experimental analysis. J. Phys. Conf. Ser. 2014, 501, 012028. [CrossRef]

29. Orejon, D.; Shardt, O.; Gunda, N.S.K.; Ikuta, T.; Takahashi, K.; Takata, Y.; Mitra, S.K. Simultaneous dropwise and filmwise condensation on hydrophilic microstructured surfaces. Int. J. Heat Mass Transf. 2017, 114, 187-197. [CrossRef]

30. Su, J.; Inalpolat, M.; Ge, T.; Esmaeilzadeh, H.; Sun, H. Experimental study and analysis of dropwise condensation using quartz. In Proceedings of the ASME 2016 Heat Transfer Summer Conference collocated with the ASME 2016 Fluids Engineering Division Summer Meeting and the ASME 2016 14th International Conference on Nanochannels, Microchannels, and Minichannels, Washington, DC, USA, 10-14 July 2016.

31. Gusarov, A.V.; Smurov, I. Gas-dynamic boundary conditions of evaporation and condensation: Numerical analysis of the Knudsen layer. Phys. Fluids 2002, 14, 4242-4255. [CrossRef]

32. Zhu, T.; Ye, W. Theoretical and numerical studies of noncontinuum gas-phase heat conduction in micro/nano devices. Numer. Heat Transf. Part B Fundam. 2010, 57, 203-226. [CrossRef]

33. Liu, H.; Xu, K.; Zhu, T.; Ye, W. Multiple temperature kinetic model and its applications to micro-scale gas flows. Comput. Fluids 2012, 67, 115-122. [CrossRef]

34. Zheng, S.; Eimann, F.; Fieback, T.; Xie, G.; Gross, U. Numerical investigation of convective dropwise condensation flow by a hybrid thermal lattice Boltzmann method. Appl. Therm. Eng. 2018, 145, 590-602. [CrossRef]

35. Gore, G.B.; Sali, N.V.; Ghodake, A.B. Of dropwise condensation heat transfer enhancement on silver coated copper surface using n-Heptane as surfactant additive. Int. Adv. Res. J. Sci. Eng. Technol. 2016, 3, 291-294.

36. Kashchiev, D. Nucleation: Basic Theory with Applications; Butterworth Heinemann: Oxford, UK, 2000.

37. Bergman, T.L.; Incropera, F.P.; DeWitt, D.P.; Lavine, A.S. Fundamentals of Heat and Mass Transfer; John Wiley \& Sons: Hoboken, NJ, USA, 2011.

38. Lv, C.; Hao, P.; Zhang, X.; He, F. Dewetting transitions of dropwise condensation on nanotexture-enhanced superhydrophobic surfaces. ACS Nano 2015, 9, 12311-12319. [CrossRef]

39. Chen, L.-H.; Chen, C.-Y.; Lee, Y.-L. Nucleation and growth of clusters in the process of vapor deposition. Surf. Sci. 1999, 429, 150-160. [CrossRef]

40. Glassford, A.P.M. Practical model for molecular contaminant deposition kinetics. J. Thermophys. Heat Transf. 1992, 6, 656-664. [CrossRef]

41. Westwater, J.W. Gold surfaces for condensation heat transfer. Gold Bull. 1981, 14, 95-101. [CrossRef]

42. Boreyko, J.B.; Chen, C.-H. Self-propelled dropwise condensate on superhydrophobic surfaces. Phys. Rev. Lett. 2009, 103, 184501. [CrossRef]

43. Miljkovic, N.; Wang, E.N. Condensation heat transfer on superhydrophobic surfaces. MRS Bull. 2013, 38, 397-406. [CrossRef]

44. Rose, J.W.; Spalding, D.B. Interphase matter transfer, the condensation coefficient and dropwise condensation. Proc. R. Soc. Lond. A 1987, 1841, 305-311. [CrossRef]

45. Carey, V.P. Liquid-Vapor Phase-Change Phenomena, 2nd ed.; Taylor \& Francis Group: New York, NY, USA, 2008.

46. Mikic, B.B. On mechanism of dropwise condensation. Int. J. Heat Mass Transf. 1969, 12, 1311-1323. [CrossRef]

47. Rose, J.W. Dropwise condensation theory and experiment: A review. Proc. Inst. Mech. Eng. Part A J. Power Energy 2002, 216, 115-128. [CrossRef]

48. Rose, J.W. Condensation overview. In A-to-Z Guide to Thermodynamics, Heat and Mass Transfer, and Fluids Engineering; Begell House: Danbury, CT, USA, 2011.

49. Leipertz, A.; Fröba, A.P. Improvement of condensation heat transfer by surface modifications. Heat Transf. Eng. 2008, 29, 343-356. [CrossRef]

50. Schmidt, E.; Schurig, W.; Sellschopp, W. Versuche über die Kondensation von Wasserdampf in Film- und Tropfenform. Tech. Mech. Thermodyn. 1930, 1, 53-63. [CrossRef]

51. Tanasawa, I. Advances in condensation heat transfer. Adv. Heat Transf. 1991, 21, 55-139.

52. Al-Shammari, S.B.; Webb, D.R.; Heggs, P. Condensation of steam with and without the presence of non-condensable gases in a vertical tube. Desalination 2004, 169, 151-160. [CrossRef]

53. Fu, W.; Li, X.; Wu, X.; Corradini, M.L. Numerical investigation of convective condensation with the presence of non-condensable gases in a vertical tube. Nucl. Eng. Des. 2016, 297, 197-207. [CrossRef] 
54. Kroger, D.G.; Rohsenow, W.M. Condensation heat transfer in the presence of a non-condensable gas. Int. J. Heat Mass Transf. 1968, 11, 15-26. [CrossRef]

55. Martín-Valdepeñas, J.M.; Jiménez, M.A.; Martín-Fuertes, F.; Benítez, J.A.F. Comparison of film condensation models in presence of non-condensable gases implemented in a CFD Code. Heat Mass Transf. 2005, 41, 961-976. [CrossRef]

56. Citakoglu, E.; Rose, J.W. Dropwise condensation-some factors influencing the validity of heat-transfer measurements. Int. J. Heat Mass Transf. 1968, 11, 523-537. [CrossRef]

57. Le Fevre, E.J.; Rose, J.W. An experimental study of heat transfer by dropwise condensation. Int. J. Heat Mass Transf. 1965, 8, 1117-1133. [CrossRef]

58. Lee, J.; Shao, B.; Won, Y. Two-level copper oxide nanostructured surfaces for condensation heat transfer. In Proceedings of the 2018 17th IEEE Intersociety Conference on Thermal and Thermomechanical Phenomena in Electronic Systems (ITherm), San Diego, CA, USA, 29 May-1 June 2018; pp. 12-18.

59. Lee, Y.A.; Kuo, L.S.; Su, T.W.; Hsu, C.C.; Chen, P.H. Orientation effects of nanoparticle-modified surfaces with interlaced wettability on condensation heat transfer. Appl. Therm. Eng. 2016, 98, 1054-1060. [CrossRef]

60. Niu, D.; Tang, G.H. The effect of surface wettability on water vapor condensation in nanoscale. Sci. Rep. 2016, 6, 19192. [CrossRef]

61. Jaikumar, A.; Gupta, A.; Kandlikar, S.G.; Yang, C.Y.; Su, C.Y. Scale effects of graphene and graphene oxide coatings on pool boiling enhancement mechanisms. Int. J. Heat Mass Transf. 2017, 109, 357-366. [CrossRef]

62. Enright, R.; Miljkovic, N.; Alvarado, J.L.; Kim, K.; Rose, J.W. Dropwise condensation on micro- and nanostructured surfaces. Nanoscale Microscale Thermophys. Eng. 2014, 18, 223-250. [CrossRef]

63. Mondal, B.; Mac Giolla Eain, M.; Xu, Q.; Egan, V.M.; Punch, J.; Lyons, A.M. Design and fabrication of a hybrid superhydrophobic-hydrophilic surface that exhibits stable dropwise condensation. ACS Appl. Mater. Interfaces 2015, 7, 23575-23588. [CrossRef]

64. Zhang, B.J.; Kuok, C.; Kim, K.J.; Hwang, T.; Yoon, H. Dropwise steam condensation on various hydrophobic surfaces: Polyphenylene sulfide (PPS), polytetrafluoroethylene (PTFE), and self-assembled micro/nano silver (SAMS). Int. J. Heat Mass Transf. 2015, 89, 353-358. [CrossRef]

65. Preston, D.J.; Mafra, D.L.; Miljkovic, N.; Kong, J.; Wang, E.N. Scalable graphene coatings for enhanced condensation heat transfer. Nano Lett. 2015, 15, 2902-2909. [CrossRef] [PubMed]

66. Hu, H.W.; Tang, G.H.; Niu, D. Experimental investigation of condensation heat transfer on hybrid wettability finned tube with large amount of noncondensable gas. Int. J. Heat Mass Transf. 2015, 85, 513-523. [CrossRef]

67. Young, T. An essay on the cohesion of fluids. Philos. Trans. R. Soc. Lond. 1832, 95, 171-172. [CrossRef]

68. Wenzel, R.N. Resistance of solid surfaces to wetting by water. Ind. Eng. Chem. 1936, 28, 988-994. [CrossRef]

69. Cassie, A.B.D.; Baxter, S. Wettability of porous surfaces. Trans. Faraday Soc. 1944, 40, 546-551. [CrossRef]

70. Lafuma, A.; Quéré, D. Superhydrophobic states. Nat. Mater. 2003, 2, 457-460. [CrossRef] [PubMed]

71. Alwazzan, M.; Egab, K.; Peng, B.; Khan, J.; Li, C. Condensation on hybrid-patterned copper tubes (I): Characterization of condensation heat transfer. Int. J. Heat Mass Transf. 2017, 112, 991-1004. [CrossRef]

72. Xiao, R.; Miljkovic, N.; Enright, R.; Wang, E.N. Immersion condensation on oil-infused heterogeneous surfaces for enhanced heat transfer. Sci. Rep. 2013, 3, 1988. [CrossRef] [PubMed]

73. Das, A.K.; Kilty, H.P.; Marto, P.J.; Andeen, G.B.; Kumar, A. The use of an organic self-assembled monolayer coating to promote dropwise condensation of steam on horizontal tubes. J. Heat Transf. 2000, 122, 278-286. [CrossRef]

74. Torresin, D.; Tiwari, M.K.; Del Col, D.; Poulikakos, D. Flow condensation on copper-based nanotextured superhydrophobic surfaces. Langmuir 2013, 29, 840-848. [CrossRef] [PubMed]

75. Feng, J.; Qin, Z.; Yao, S. Factors affecting the spontaneous motion of condensate drops on superhydrophobic copper surfaces. Langmuir 2012, 28, 6067-6075. [CrossRef] [PubMed]

76. Koch, G.; Zhang, D.C.; Leipertz, A. Condensation of steam on the surface of hard coated copper discs. Heat Mass Transf. 1997, 32, 149-156. [CrossRef]

77. Holden, K.M.; Wanniarachchi, A.S.; Marto, P.J.; Boone, D.H.; Rose, J.W. The use of organic coatings to promote dropwise condensation of steam. J. Heat Transf. 1987, 109, 768-774. [CrossRef]

78. Marto, P.J.; Looney, D.J.; Rose, J.W.; Wanniarachchi, A.S. Evaluation of organic coatings for the promotion of dropwise condensation of steam. Int. J. Heat Mass Transf. 1986, 29, 1109-1117. [CrossRef]

79. Sezer, N.; Koc, M. Dispersion stability of CNT and CNT/Metal-based nanofluids. In Proceedings of the ICTEA 2018: 11th International Conference on Thermal Engineering, Doha, Qatar, 25-28 February 2018. 
80. Mori, K.; Fujita, N.; Horie, H.; Mori, S.; Miyashita, T.; Matsuda, M. Heat transfer promotion of an aluminum-brass cooling tube by surface treatment with triazinethiols. Langmuir 1991, 7, 1161-1166. [CrossRef]

81. Erb, R.A. Wettability of metals under continuous condensing conditions. J. Phys. Chem. 1965, 69, 1306-1309. [CrossRef]

82. Erb, R.A. Dropwise condensation on gold. Gold Bull. 1973, 6, 2-6. [CrossRef]

83. Wilkins, D.G.; Bromley, L.A.; Read, S.M. Dropwise and filmwise condensation of water vapor on gold. AIChE J. 1973, 19, 119-123. [CrossRef]

84. Erb, R.; Thelen, E. Promoting permanent dropwise condensation. Ind. Eng. Chem. 1965, 57, 49-52. [CrossRef]

85. Woodruff, D.W.; Westwater, J.W. Steam condensation on electroplated gold: effect of plating thickness. Int. J. Heat Mass Transf. 1979, 22, 629-632. [CrossRef]

86. Woodruff, D.W.; Westwater, J.W. Steam condensation on various gold surfaces. J. Heat Transf. 1981, 103, 685-692. [CrossRef]

87. Smith, T. The hydrophilic nature of a clean gold surface. J. Colloid Interface Sci. 1980, 75, 51-55. [CrossRef]

88. O'neill, G.A.; Westwater, J.W. Dropwise condensation of steam on electroplated silver surfaces. Int. J. Heat Mass Transf. 1984, 27, 1539-1549. [CrossRef]

89. Ge, M.; Wang, S.; Zhao, J.; Zhao, Y.; Liu, L. Effects of extended surface and surface gold plating on condensation characteristics of steam with large amount of $\mathrm{CO}_{2}$. Exp. Therm. Fluid Sci. 2018, 92, 13-19. [CrossRef]

90. Habib, M.A.; Tahir, F.; Nemitallah, M.A.; Ahmed, W.H.; Badr, H.M. Experimental and numerical analysis of oxy-fuel combustion in a porous plate reactor. Int. J. Energy Res. 2015, 39, 1229-1240. [CrossRef]

91. Thiel, G.P.; Lienhard, J.H. Entropy generation in condensation in the presence of high concentrations of noncondensable gases. Int. J. Heat Mass Transf. 2012, 55, 5133-5147. [CrossRef]

92. Erb, R.A.; Thelen, E. Dropwise condensation. In Proceedings of the First International Sympposium on Water Desalination, Washington, DC, USA, 3-9 October 1965.

93. Di Luzio, F.C.; Sieder, E.N.; Cadwallader, E.A. Research and Development Progress Report No. 184 Dropwise Condensation Characteristics of Permanent Hydrophobic Systems; Franklin Institute: Philadelphia, PA, USA, 1966.

94. Azimi, G.; Kwon, H.-M.; Varanasi, K.K. Superhydrophobic surfaces by laser ablation of rare-earth oxide ceramics. MRS Commun. 2014, 4, 95-99. [CrossRef]

95. Zenkin, S.; Kos, Š.; Musil, J. Hydrophobicity of thin films of compounds of low-electronegativity metals. J. Am. Ceram. Soc. 2014, 97, 2713-2717. [CrossRef]

96. Azimi, G.; Dhiman, R.; Kwon, H.-M.; Paxson, A.T.; Varanasi, K.K. Hydrophobicity of rare-earth oxide ceramics. Nat. Mater. 2013, 12, 315-320. [CrossRef]

97. Khan, S.; Azimi, G.; Yildiz, B.; Varanasi, K.K. Role of surface oxygen-to-metal ratio on the wettability of rare-earth oxides. Appl. Phys. Lett. 2015, 106, 061601. [CrossRef]

98. Preston, D.J.; Miljkovic, N.; Sack, J.; Enright, R.; Queeney, J.; Wang, E.N. Effect of hydrocarbon adsorption on the wettability of rare earth oxide ceramics. Appl. Phys. Lett. 2014, 105, 011601. [CrossRef]

99. Lundy, R.; Byrne, C.; Bogan, J.; Nolan, K.; Collins, M.N.; Dalton, E.; Enright, R. Exploring the role of adsorption and surface state on the hydrophobicity of rare earth oxides. ACS Appl. Mater. Interfaces 2017, 9, 13751-13760. [CrossRef] [PubMed]

100. Khan, S.M.K. Hydrophobicity of Rare-Earth Oxide Ceramics and Their Application in Promoting Sustained Drop-Wise Condensation. Ph.D. Thesis, Massachusetts Institute of Technology (MIT), Cambridge, MA, USA, February 2016.

101. Shim, J.; Seo, D.; Oh, S.; Lee, J.; Nam, Y. Condensation heat-transfer performance of thermally stable superhydrophobic cerium-oxide surfaces. ACS Appl. Mater. Interfaces 2018, 10, 31765-31776. [CrossRef] [PubMed]

102. Zhang, D.; Lin, Z.; Lin, J. New surface materials for dropwise condensation. In Proceedings of the 8th International Heat Transfer Conference, San Francisco, CA, USA, 17-22 August 1986.

103. Zhao, Q.; Zhang, D.; Lin, J. Surface material with dropwise condensation made by ion implantation technology. Int. J. Heat Mass Transf. 1991, 34, 2833-2835.

104. Zhao, Q.; Burnside, B.M. Dropwise condensation of steam on ion implanted condenser surfaces. Heat Recovery Syst. CHP 1994, 14, 525-534. [CrossRef] 
105. Rausch, M.H.; Leipertz, A.; Fröba, A.P. On the characteristics of ion implanted metallic surfaces inducing dropwise condensation of steam. Langmuir 2010, 26, 5971-5975. [CrossRef] [PubMed]

106. Rausch, M.H.; Leipertz, A.; Fröba, A.P. Dropwise condensation of steam on ion implanted titanium surfaces. Int. J. Heat Mass Transf. 2010, 53, 423-430. [CrossRef]

107. Rausch, M.H.; Leipertz, A.; Fröba, A.P. Experimental study on the origin of dropwise condensation of steam on ion implanted metallic surfaces. In Proceedings of the 2010 14th International Heat Transfer Conference, Washington, DC, USA, 8-13 August 2010; pp. 19-24.

108. Do, S.C.; Kim, K.W.; Jeong, J.H. The variation of hydrophobicity of aluminum alloy by nitrogen and argon ion implantation. Heat Mass Transf. 2015, 51, 487-495. [CrossRef]

109. Bani Kananeh, A.; Rausch, M.H.; Fröba, A.P.; Leipertz, A. Experimental study of dropwise condensation on plasma-ion implanted stainless steel tubes. Int. J. Heat Mass Transf. 2006, 49, 5018-5026. [CrossRef]

110. Guo, Y.-C.; Wang, Z.X. Amorphous Physics; Science: Beijing, China, 1984. (In Chinese)

111. Kim, K.; Lee, Y.; Jeong, J.H. Dropwise condensation induced on chromium ion implanted aluminum surface. Nucl. Eng. Technol. 2019, 51, 84-94. [CrossRef]

112. Diezel, L.L.; Fröba, A.P.; Lukić, N.; Leipertz, A. Optimierung einer auf dem Verfahren der mechanischen Brüdenverdichtung basierenden Meerwasserentsalzungsanlage. Chem. Ing. Tech. 2007, 79, 459-467. [CrossRef]

113. Lukic, N.; Diezel, L.L.; Fröba, A.P.; Leipertz, A. Economical aspects of the improvement of a mechanical vapour compression desalination plant by dropwise condensation. Desalination 2010, 264, 173-178. [CrossRef]

114. Ma, X.; Chen, J.; Xu, D.; Lin, J.; Ren, C.; Long, Z. Influence of processing conditions of polymer film on dropwise condensation heat transfer. Int. J. Heat Mass Transf. 2002, 45, 3405-3411. [CrossRef]

115. Haraguchi, T.; Shimada, R.; Kumagai, S.; Takeyama, T. The effect of polyvinylidene chloride coating thickness on promotion of dropwise steam condensation. Int. J. Heat Mass Transf. 1991, 34, 3047-3054. [CrossRef]

116. Miljkovic, N.; Preston, D.J.; Enright, R.; Wang, E.N. Electrostatic charging of jumping droplets. Nat. Commun. 2013, 4, 2517. [CrossRef] [PubMed]

117. Gupta, M.; Kapur, V.; Pinkerton, N.M.; Gleason, K.K. Initiated chemical vapor deposition (iCVD) of conformal polymeric nanocoatings for the surface modification of high-aspect-ratio pores. Chem. Mater. 2008, 20, 1646-1651. [CrossRef]

118. Paxson, A.T.; Yagüe, J.L.; Gleason, K.K.; Varanasi, K.K. Stable dropwise condensation for enhancing heat transfer via the initiated chemical vapor deposition (iCVD) of grafted polymer films. Adv. Mater. 2014, 26, 418-423. [CrossRef]

119. Uçar, I.O.; Erbil, H.Y. Droplet condensation on polymer surfaces: A review. Turkish J. Chem. 2013, 37, 643-674.

120. Haque, M.R.; Zhu, C.; Qu, C.; Kinzel, E.C.; Betz, A.R. Experimental investigation of condensation phenomenon on hydrophilic and hydrophobic titanium (Ti) pillared glass surfaces. In Proceedings of the 6th Micro Nano Flows Conference, Atlanta, GA, USA, 9-12 September 2018.

121. Ji, X.; Zhou, D.; Dai, C.; Xu, J. Dropwise condensation heat transfer on superhydrophilic-hydrophobic network hybrid surface. Int. J. Heat Mass Transf. 2019, 132, 52-67. [CrossRef]

122. Tsuchiya, H.; Manabe, K.; Gaudelet, T.; Moriya, T.; Suwabe, K.; Tenjimbayashi, M.; Kyong, K.H.; Gillot, F.; Shiratori, S. Improvement of heat transfer by promoting dropwise condensation using electrospun polytetrafluoroethylene thin films. New J. Chem. 2017, 41, 982-991. [CrossRef]

123. Huang, D.-J.J.; Leu, T.-S.S. Condensation heat transfer enhancement by surface modification on a monolithic copper heat sink. Appl. Therm. Eng. 2015, 75, 908-917. [CrossRef]

124. Schroeder-Richter, D.; Yildiz, S.; Bartsch, G. Effect of porous coating on critical heat flux. Int. Commun. Heat Mass Transf. 1996, 23, 463-471. [CrossRef]

125. Yang, Q.; Gu, A. Dropwise condensation on SAM and electroless composite coating surfaces. J. Chem. Eng. Japan 2006, 39, 826-830. [CrossRef]

126. Vemuri, S.; Kim, K.J.; Wood, B.D.; Govindaraju, S.; Bell, T.W. Long term testing for dropwise condensation using self-assembled monolayer coatings of n-octadecyl mercaptan. Appl. Therm. Eng. 2006, 26, 421-429. [CrossRef]

127. Chen, L.; Liang, S.; Yan, R.; Cheng, Y.; Huai, X.; Chen, S. n-Octadecanethiol self-assembled monolayer coating with microscopic roughness for dropwise condensation of steam. J. Therm. Sci. 2009, 18, 160-165. [CrossRef] 
128. Chandekar, A.; Sengupta, S.K.; Whitten, J.E. Thermal stability of thiol and silane monolayers: A comparative study. Appl. Surf. Sci. 2010, 256, 2742-2749. [CrossRef]

129. Xue, C.-H.; Ma, J.-Z. Long-lived superhydrophobic surfaces. J. Mater. Chem. A 2013, 1, 4146-4161. [CrossRef]

130. Li, Y.; Li, L.; Sun, J. Bioinspired self-healing superhydrophobic coatings. Angew. Chemie Int. Ed. 2010, 49, 6129-6133. [CrossRef] [PubMed]

131. Anand, S.; Paxson, A.T.; Dhiman, R.; Smith, J.D.; Varanasi, K.K. Enhanced condensation on lubricant-impregnated nanotextured surfaces. ACS Nano 2012, 6, 10122-10129. [CrossRef] [PubMed]

132. Wong, T.-S.; Kang, S.H.; Tang, S.K.Y.; Smythe, E.J.; Hatton, B.D.; Grinthal, A.; Aizenberg, J. Bioinspired self-repairing slippery surfaces with pressure-stable omniphobicity. Nature 2011, 477, 443-447. [CrossRef] [PubMed]

133. Lafuma, A.; Quéré, D. Slippery pre-suffused surfaces. EPL (Europhys. Lett.) 2011, 96, 56001. [CrossRef]

134. Epstein, A.K.; Wong, T.-S.; Belisle, R.A.; Boggs, E.M.; Aizenberg, J. Liquid-infused structured surfaces with exceptional anti-biofouling performance. Proc. Natl. Acad. Sci. 2012, 109, 13182-13187. [CrossRef] [PubMed]

135. Hejazi, V.; Nosonovsky, M. Wetting transitions in two-, three-, and four-phase systems. Langmuir 2012, 28, 2173-2180. [CrossRef] [PubMed]

136. Quan, X.; Chen, S.; Li, J.; Cheng, P. Enhanced dropwise condensation by oil infused nano-grass coatings on outer surface of a horizontal copper tube. Int. Commun. Heat Mass Transf. 2018, 91, 11-16. [CrossRef]

137. Weisensee, P.B.; Wang, Y.; Qian, H.; Schultz, D.; King, W.P.; Miljkovic, N. Condensate droplet size distribution on lubricant-infused surfaces. Int. J. Heat Mass Transf. 2017, 109, 187-199. [CrossRef]

138. Daniel, D.; Mankin, M.N.; Belisle, R.A.; Wong, T.-S.; Aizenberg, J. Lubricant-infused micro/nano-structured surfaces with tunable dynamic omniphobicity at high temperatures. Appl. Phys. Lett. 2013, 102, 231603. [CrossRef]

139. Preston, D.J.; Lu, Z.; Song, Y.; Zhao, Y.; Wilke, K.L.; Antao, D.S.; Louis, M.; Wang, E.N. Heat transfer enhancement during water and hydrocarbon condensation on lubricant infused surfaces. Sci. Rep. 2018, 8, 540. [CrossRef]

140. Chen, X.; Akinwande, D.; Lee, K.-J.; Close, G.F.; Yasuda, S.; Paul, B.C.; Fujita, S.; Kong, J.; Wong, H.-S.P. Fully integrated graphene and carbon nanotube interconnects for gigahertz high-speed CMOS electronics. IEEE Trans. Electron Devices 2010, 57, 3137-3143. [CrossRef]

141. Li, X.; Zhu, Y.; Cai, W.; Borysiak, M.; Han, B.; Chen, D.; Piner, R.D.; Colombo, L.; Ruoff, R.S. Transfer of large-area graphene films for high-performance transparent conductive electrodes. Nano Lett. 2009, 9, 4359-4363. [CrossRef]

142. Kim, P.; Shi, L.; Majumdar, A.; McEuen, P.L. Thermal transport measurements of individual multiwalled nanotubes. Phys. Rev. Lett. 2001, 87, 215502. [CrossRef]

143. Chen, C.-H.; Cai, Q.; Tsai, C.; Chen, C.-L.; Xiong, G.; Yu, Y.; Ren, Z. Dropwise condensation on superhydrophobic surfaces with two-tier roughness. Appl. Phys. Lett. 2007, 90, 173108. [CrossRef]

144. Kim, M.-S.; Ada, K.A.L.; Kwon, O.K.; Park, C.W. A comparison of condensation heat transfer performance of MWCNT/Fe composite coatings on steel substrate. J. Mech. Sci. Technol. 2014, 28, 1589-1596. [CrossRef]

145. Koch, G.; Kraft, K.; Leipertz, A. Parameter study on the performance of dropwise condensation. Revue Générale de Thermique 1998, 37, 539-548. [CrossRef]

146. Preston, D.J.; Wang, E.N. Jumping droplets push the boundaries of condensation heat transfer. Joule 2018, 2, 205-207. [CrossRef]

147. Ko, T.-J.; Her, E.K.; Shin, B.; Kim, H.-Y.; Lee, K.-R.; Hong, B.K.; Kim, S.H.; Oh, K.H.; Moon, M.-W. Water condensation behavior on the surface of a network of superhydrophobic carbon fibers with high-aspect-ratio nanostructures. Carbon 2012, 50, 5085-5092. [CrossRef]

148. Zhao, Q.; Zhang, D.C.; Lin, J.F.; Wang, G.M. Dropwise condensation on L-B film surface. Chem. Eng. Process. Process Intensif. 1996, 35, 473-477. [CrossRef]

149. Quan, X.; Wang, D.; Cheng, P. An experimental investigation on wettability effects of nanoparticles in pool boiling of a nanofluid. Int. J. Heat Mass Transf. 2017, 108, 32-40. [CrossRef]

150. Lan, Z.; Chen, Y.; Hu, S.; Yin, G.; Ma, X. Droplet regulation and dropwise condensation heat transfer enhancement on hydrophobic-superhydrophobic hybrid surfaces. Heat Transf. Eng. 2018, 39, 1543-1554. [CrossRef]

151. Dong, J.; Dong, H.; Jin, Y.; Sun, L.; Ye, S. Nanograssed Micro-V-Groove architectures for continuous dropwise condensation and droplet directional movement. Adv. Mater. Interfaces 2018, 5, 1800202. [CrossRef] 
152. Park, K.-C.; Kim, P.; Grinthal, A.; He, N.; Fox, D.; Weaver, J.C.; Aizenberg, J. Condensation on slippery asymmetric bumps. Nature 2016, 531, 78-82. [CrossRef]

153. Bahrami, H.R.T.; Saffari, H. Theoretical study of stable dropwise condensation on an inclined micro/nano-structured tube. Int. J. Refrig. 2017, 75, 141-154. [CrossRef]

154. Cheng, J. Resistant energy analysis of dropwise condensation on superhydrophobic surfaces with hierarchical roughness. In Proceedings of the Fluids Engineering Division Summer Meeting 2017, Waikoloa, HI, USA, 30 July-3 August 2017; p. V01CT24A001.

155. Parin, R.; Martucci, A.; Sturaro, M.; Bortolin, S.; Bersani, M.; Carraro, F.; Del Col, D. Nano-structured aluminum surfaces for dropwise condensation. Surf. Coat. Technol. 2018, 348, 1-12. [CrossRef]

156. Zhu, J.; Luo, Y.; Tian, J.; Li, J.; Gao, X. Clustered ribbed-nanoneedle structured copper surfaces with high-efficiency dropwise condensation heat transfer performance. ACS Appl. Mater. Interfaces 2015, 7, 10660-10665. [CrossRef] [PubMed]

157. Xie, J.; Xu, J.; Li, X.; Liu, H. Dropwise condensation on superhydrophobic nanostructure surface, Part I: Long-term operation and nanostructure failure. Int. J. Heat Mass Transf. 2019, 129, 86-95. [CrossRef]

158. Parin, R.; Del Col, D.; Bortolin, S.; Martucci, A. Dropwise condensation over superhydrophobic aluminium surfaces. J. Phys. Conf. Ser. 2016, 745, 032134. [CrossRef]

159. Chen, X.; Weibel, J.A.; Garimella, S.V. Exploiting microscale roughness on hierarchical superhydrophobic copper surfaces for enhanced dropwise condensation. Adv. Mater. Interfaces 2015, 2, 1400480. [CrossRef]

160. Zhao, Y.; Luo, Y.; Zhu, J.; Li, J.; Gao, X. Copper-based ultrathin nickel nanocone films with high-efficiency dropwise condensation heat transfer performance. ACS Appl. Mater. Interfaces 2015, 7, 11719-11723. [CrossRef]

161. Wen, R.; Li, Q.; Wu, J.; Wu, G.; Wang, W.; Chen, Y.; Ma, X.; Zhao, D.; Yang, R. Hydrophobic copper nanowires for enhancing condensation heat transfer. Nano Energy 2017, 33, 177-183. [CrossRef]

162. Qu, M.; Liu, J.; He, J. Fabrication of copper-based $\mathrm{ZnO}$ nanopencil arrays with high-efficiency dropwise condensation heat transfer performance. RSC Adv. 2016, 6, 59405-59409. [CrossRef]

163. Lu, M.-C.; Lin, C.-C.; Lo, C.-W.; Huang, C.-W.; Wang, C.-C. Superhydrophobic Si nanowires for enhanced condensation heat transfer. Int. J. Heat Mass Transf. 2017, 111, 614-623. [CrossRef]

164. Wen, R.; Xu, S.; Ma, X.; Lee, Y.-C.; Yang, R. Three-dimensional superhydrophobic nanowire networks for enhancing condensation heat transfer. Joule 2018, 2, 269-279. [CrossRef]

165. Preston, D.J.; Lu, Z.; Zhao, Y.; Antao, D.; Wilke, K.; Wang, E.N. Optimal design of slippery liquid-infused porous surfaces for enhanced condensation of low surface tension fluids. In Proceedings of the APS March Meeting 2017, New Orleans, LA, USA, 13-17 March 2017.

166. Tsuchiya, H.; Tenjimbayashi, M.; Moriya, T.; Yoshikawa, R.; Sasaki, K.; Togasawa, R.; Yamazaki, T.; Manabe, K.; Shiratori, S. Liquid-infused smooth surface for improved condensation heat transfer. Langmuir 2017, 33, 8950-8960. [CrossRef] [PubMed]

167. Hoenig, S.H.; Bonner, R.W., III. Dropwise condensation on hydrophobic microporous powder and the transition to intrapowder droplet removal. In Proceedings of the 3rd Thermal and Fluids Engineering Conference (TFEC), Fort Lauderdale, FL, USA, 4-7 March 2018; pp. 643-653.

168. Hoenig, S.H.; Bonner, R.W. Dropwise condensation on superhydrophobic microporous wick structures. J. Heat Transf. 2018, 140, 071501. [CrossRef]

169. Zhu, L.; Xiu, Y.; Xu, J.; Tamirisa, P.A.; Hess, D.W.; Wong, C.-P. Superhydrophobicity on two-tier rough surfaces fabricated by controlled growth of aligned carbon nanotube arrays coated with fluorocarbon. Langmuir 2005, 21, 11208-11212. [CrossRef] [PubMed]

170. Ahlers, M.; Buck-Emden, A.; Bart, H.-J. Is dropwise condensation feasible? A review on surface modifications for continuous dropwise condensation and a profitability analysis. J. Adv. Res. 2018, in press. [CrossRef]

171. Watson, R.C.H.; Birt, D.C.P.; Honour, C.W.; Ash, B.W. The promotion of dropwise condensation by montan wax. I. Heat transfer measurements. J. Appl. Chem. 1962, 12, 539-546. [CrossRef]

172. Ma, X.; Rose, J.W.; Xu, D.; Lin, J.; Wang, B. Advances in dropwise condensation heat transfer: Chinese research. Chem. Eng. J. 2000, 78, 87-93. [CrossRef]

(C) 2019 by the authors. Licensee MDPI, Basel, Switzerland. This article is an open access article distributed under the terms and conditions of the Creative Commons Attribution (CC BY) license (http:/ / creativecommons.org/licenses/by/4.0/). 